\title{
New constraints on the metamorphic evolution of the Eastern Ghats Belt, India, based on relict composite inclusions in garnet from ultrahigh-temperature sapphirine granulites
}

\author{
C. V. DHARMA RAO ${ }^{1 *}$ and REIA M. CHMIELOWSKI ${ }^{2}$ \\ ${ }^{1}$ National Disaster Management Authority, Government of India, A-1 Safdarjung Enclave, New Delhi, India \\ ${ }^{2}$ Dipartimento di Scienze della Terra, Università degli Studi di Milano, Italy
}

\begin{abstract}
The sapphirine granulites from Gangaraju Madugula, Eastern Ghats Belt (EGB), India preserve a rich variety of mineral assemblages and unique isolated and composite mineral inclusions within garnet that provide robust evidence for extreme crustal metamorphism at ultrahigh temperature $(\mathrm{UHT})$ conditions $\left(>900^{\circ} \mathrm{C}\right)$. Diagnostic UHT assemblages in these rocks include sapphirine + quartz, spinel + quartz and high alumina orthopyroxene + sillimanite + quartz. The stability of spinel + quartz, sapphirine + quartz and orthopyroxene + sillimanite + quartz assemblages provides evidence for temperatures exceeding $960^{\circ} \mathrm{C}$ at moderate pressures. The mineral association of garnet-orthopyroxene is indicative of a subsequent high $P$-UHT metamorphic event as indicated by the high alumina contents of orthopyroxene $\left(>10 \mathrm{wt} \% \mathrm{Al}_{2} \mathrm{O}_{3}\right)$ coexisting with garnet. Peak $P-T$ conditions of $\sim 970^{\circ} \mathrm{C}$ and $9.5 \mathrm{kbars}$ are calculated from conventional garnet-orthopyroxene geothermobarometry. Calculated isochemical sections constructed in the model system $\mathrm{Na}_{2} \mathrm{O}-\mathrm{CaO}-\mathrm{K}_{2} \mathrm{O}-\mathrm{FeO}-\mathrm{MgO}_{-}-\mathrm{Al}_{2} \mathrm{O}_{3}-\mathrm{SiO}_{2}-\mathrm{H}_{2} \mathrm{O}-\mathrm{TiO}_{2}-\mathrm{Fe}_{2} \mathrm{O}_{3}$ (NCKFMASHTO) for the sapphirine granulites and garnet-orthopyroxene granulites adequately predict phase relationships that are consistent with those observed in the rocks. An evaluation of the assemblages and textures and $P-T$ estimates indicate a three-stage evolution of the sapphirine granulites and associated garnet-orthopyroxene granulites: (1) inclusion assemblages with sapphirine, spinel and quartz on the low-pressure prograde path ( $\mathbf{M}_{1}$ stage); (2) a peak UHT assemblage of porphyroblastic garnet-orthopyroxene ( $\mathbf{M}_{2}$ stage) and (3)

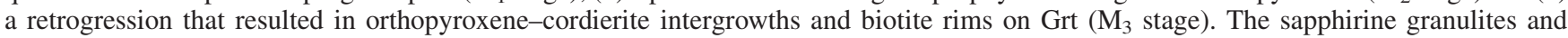
associated garnet-orthopyroxene granulites indicate that they grew during the prograde and retrograde stage. The thermo-barometric estimates from mineral compositions and the complimentary isochemical sections approached from bulk rock compositions allow tighter constraints to be placed on the $P-T$ evolution of this sector of the EGB. Copyright (C) 2010 John Wiley \& Sons, Ltd.
\end{abstract}

Received 9 November 2009; accepted 21 April 2010

KEY WORDS UHT sapphirine granulites; Eastern Ghats; garnet; NCKFMASHTO; isochemical sections

\section{INTRODUCTION}

Ultrahigh temperature (UHT) metamorphism, where temperatures are in excess of $900^{\circ} \mathrm{C}$, is the most thermally extreme type of crustal metamorphism (Kelsey, 2008). However, the peak metamorphic conditions of such UHTs are commonly obscured or overprinted by subsequent retrograde metamorphism of less extreme, yet high temperature (e.g. $800^{\circ} \mathrm{C}$ ) conditions (e.g. Moraes et al., 2002). Nevertheless, the core of coarse-grained garnet can be shielded against such overprints (Tsunogae and Santosh, 2006; Asami et al., 2007), and thus mineral assemblages preserved as inclusions in garnet cores within UHT rocks

\footnotetext{
* Correspondence to: C. V. Dharma Rao, National Disaster Management Authority, Government of India, A-1 Safdarjung Enclave, New Delhi, India. E-mail: Dharma_rao@hotmail.com
}

can provide crucial information on their prograde history. The preservation of such inclusions can, therefore, significantly expand our understanding of the $P-T$ history of high-grade metamorphic rocks. This topic has been recently discussed by several authors reconstructing prograde $P-T$ paths and/or estimating pre-peak and peak metamorphic conditions (e.g. Moraes et al., 2002; Lal, 2003; Das et al., 2006; Tsunogae and Santosh, 2006; Bose and Das, 2007; Masago et al., 2009; Nishimiya et al., 2010).

This study focuses on metapelitic granulites in the Gangaraju Madugula (hereafter referred to as G. Madugula) $\left(18.01^{\circ} \mathrm{N} 82.30^{\circ} \mathrm{E}\right)$ area located about $120 \mathrm{~km} \mathrm{NW}$ of Vishakapatnam, Andhra Pradesh, India (Figure 1). This region was selected because it exposes $\mathrm{Mg}-\mathrm{Al}$-rich metamorphic units which have experienced high temperatures and are characterized by diagnostic mineral assemblages such as sapphirine + quartz (Dallwitz, 1968; 

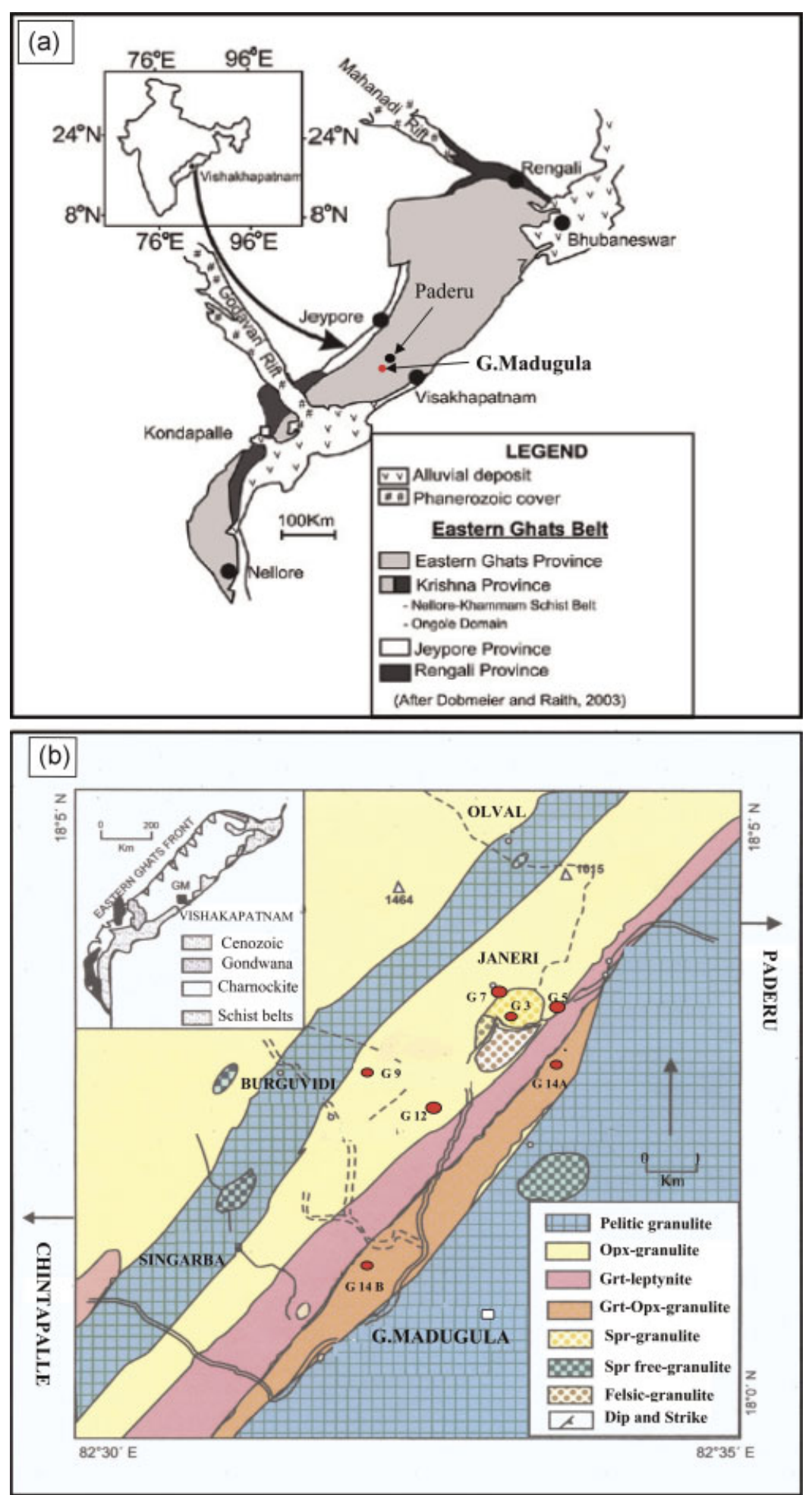

Figure 1. (a) The Eastern Ghats Belt, India showing different domains and the location of G. Madugula. (b) A simplified geological sketch map of G. Madugula, showing distribution of rock units and sample locations (simplified after Mohan et al., 1997). This figure is available in colour online at wileyonlinelibrary.com/journal/gj. 
Ellis et al., 1980; Grew, 1980) and orthopyroxene + sillimanite + quartz (Hensen and Green, 1973) (Harley, 2004; Santosh et al., 2007, 2009a; Kelsey, 2008). The units studied include metapelitic granulites (garnet-sillimanitequartz-K-feldspar gneisses), high $\mathrm{Mg}-\mathrm{Al}$ sapphirine granulites, garnet-orthopyroxene granulites, orthopyroxene granulites, charnockite enderbites and leptynites.

The aims of this paper are: (1) to present the petrography of samples that contain mineral assemblages suitable for interpreting the $P-T$ evolution of this region of the Eastern Ghats Belt (EGB), (2) to extract information from the assemblages and textures of the garnet-hosted isolated and composite mineral inclusions; (3) to conduct a detailed $P-T$ analysis of the evolution of these rocks using both conventional thermobarometry and calculated isochemical sections and (4) discuss the results of this study within the context of the broader scenario of the evolution of the EGB and UHT rocks in the terrane in general.

\section{GEOLOGICAL SETTING}

The EGB along the east coast of India (Figure 1) is characterized by polyphase deformation, high-grade metamorphism and vestiges of UHT metamorphism with a characteristic retrograde $P-T$ path (e.g. Dasgupta et al., 1995; Bhattacharya et al., 2001; Chetty, 2010). Recent work shows that there are domains within the belt with differing evolutionary histories (see Mukhopadhyay and Basak, 2009 for a detailed review).

\subsection{Structure of the EGB}

Structural data are available from only discrete parts of the belt. In many of these areas three major episodes of deformation are identified (Bhattacharya, 1996, 1997; Bhattacharya and Gupta, 2001; Gupta, 2004). The earliest recognizable structure in the EGB is expressed as shallow dipping $\left(10-20^{\circ}\right)$ recumbent folds $\left(\mathrm{F}_{1}\right)$ defined by the migmatitic layering in metapelites. The most pervasive planar structure is a shallowly dipping foliation $\left(\mathrm{S}_{1}\right)$ axial planar to $F_{1}$. The second-generation folds $\left(F_{2}\right)$ are commonly overturned, tight to isoclinal and occur on various scales. Coaxial relationships between $\mathrm{F}_{1}$ and $\mathrm{F}_{2}$ folds are documented in several areas (Bhattacharya, 1996; Mukhopadhyay and Bhattacharya, 1997; Sarkar et al., 2007). A third, tight to open folding event, $F_{3}$, is associated with an axial planar fabric, most prominently displayed at $\mathrm{F}_{3}$ fold hinges. $F_{3}$ folds are commonly open, upright with variably oriented axial planes (E-W trending near Chilka, $\mathrm{N}-\mathrm{S}$ trending at Salur). Correlation of the deformational events identified in different areas is problematic, and the folds of a particular generation in one area are not necessarily coeval with the folds of the corresponding generation in another area. Therefore, agreement has not been reached upon a unified deformation history for the entire EGB.

\subsection{Metamorphic history of the EGB}

A series of different metamorphic events have been documented in the EGB (see review by Dasgupta and Sengupta (2003) and references therein). In the Kondapalle region, south of Godavari Rift (Figure 1), an UHT granulite facies metamorphism, with deep crustal heating, resulted in a peak temperature greater than $1000^{\circ} \mathrm{C}$ and pressure greater than 10 kbars, followed by isobaric cooling (IBC) (Sengupta et al., 1999). North of the Godavari Rift (Figure 1), an early UHT $\left(\sim 1000^{\circ} \mathrm{C}\right)$ metamorphic event $\left(\mathrm{M}_{1}\right)$ at crustal depths of $30-35 \mathrm{~km}$ (8.4 kbars) is reported from high $\mathrm{Mg}-\mathrm{Al}$ granulites in G. Madugula (Mohan et al., 1997), and several nearby areas including Paderu (Lal et al., 1987; Pal and Bose, 1997; Bhattacharya and Kar, 2002), Anantagiri (Sengupta et al., 1990), Anakapalle (Dasgupta et al., 1994; Sanyal and Fukuoka, 1995; Rickers et al., 2001a;), Araku (Sengupta et al., 1991) and Vizianagram (Kamineni and Rao, 1988). Contrasting post-peak IBC and isothermal decompression (ITD) have been recorded from several areas in the Eastern Ghats granulite belt (Lal et al., 1987; Sengupta et al., 1990; Dasgupta et al., 1991; Dasgupta, 1993; Dasgupta et al., 1994; Sen et al., 1995; Bhattacharya, 1996; Shaw and Arima, 1996; Mohan et al., 1997). A decompressive $P-T$ path has also been described from some areas in the EGB (Lal et al., 1987; Sen et al., 1995; Mohan et al., 1997; Sarkar et al., 2003). However, opinion is sharply divided as to whether the $P-T$ path of the granulites of the EGB is clockwise or anticlockwise (Sengupta et al., 1990; Sen et al., 1995; Bhattacharya, 1996; Mohan et al., 1997; Mukhopadhyay and Bhattacharya, 1997). Recent work suggests a clockwise $P-T$ path and near ITD from high temperatures in rocks from Paderu terrane during the Neoproterozoic Era (Bhattacharya and Kar, 2002). However, in most of the areas in this region, the prograde $P-T$ trajectory is rarely documented.

\subsection{Timing of metamorphism in the EGB}

An upper-intercept zircon age of $988 \mathrm{Ma}$ from sapphirine granulite was recently obtained from Paderu (Figure 1), near the present study area (Bhattacharya et al., 2003). Elsewhere in the EGB, apparent ages of high Y monazite grains armoured in garnet of metapelitic granulites and high $\mathrm{Mg}_{-}$ Al granulites bracket the timing of early UHT metamorphism between 1250 and $1100 \mathrm{Ma}$ (Simmat and Raith, 2008). 
While differences in the tectonometamorphic histories of the various domains in EGB have been recognized, the tectonic significance of these differences remains uncertain. Likewise, since the age of most of the assemblages is poorly constrained, the significance of the extreme metamorphism and the temporal evolution of EGB also remains uncertain.

\section{METHODS}

\subsection{Laboratory techniques}

Electron Probe Micro Analysis was conducted at the National Geophysical Research Institute (NGRI), Hyderabad (for samples G-03, G-05, G-6, G-09) and at the Indian Bureau of Mines, Nagpur, India (for samples G-07, G-12, G14A, G-14AB). Both institutions use a CAMECA SX-100 EPMA. A beam current of $12 \mathrm{nA}$ and an acceleration voltage of $15 \mathrm{kV}$ were used with a beam diameter of $1 \mu \mathrm{m}$. Wavelength dispersive spectrometry was employed using four vertical spectrometers. Various standards, supplied by BRGM, France, were used to calibrate the instrument. The analysed elements along with the calibrated standard and the crystal used for Wavelength-dispersive spectroscopy (WDS) analysis are: $\mathrm{Si}$ and $\mathrm{Na}$ (albite on TAP crystal), Al (corundum on TAP crystal), Mg (periclase on TAP crystal), Ca (andradite on TAP crystal), K (orthoclase on PET crystal), Mn and $\mathrm{Ti}\left(\mathrm{MnTiO}_{3}\right.$ on LIF crystal), Fe (Hematite on LIF crystal), P (apatite on TAP crystal) and $\mathrm{Cr}$ (chromite on LLIF crystal). $\mathrm{K} \alpha \mathrm{X}$-ray emission lines of all the above elements were used for calibration. Online peak stripping and corrections were performed using PEAKSIGHT software supplied by CAMECA. After repeated analyses of respective standards listed above along with the minerals of interest, it was calculated that the error on the elements was $\pm 1 \%$. Representative compositions of minerals in the analysed samples are given in Tables 1-6 and individual mineral compositions are discussed below.

\subsection{Geothermobarometry}

The $P-T$ conditions experienced by these samples have been estimated via a two-stage approach. The first utilizes the preserved peak-metamorphic mineral compositions of garnet-orthopyroxene rocks via conventional geothermobarometry without the back calculation of mineral compositions to account for peak $\mathrm{Fe}-\mathrm{Mg}$ exchange (Fitzsimons and Harley, 1994; Harley, 1998a). The samples for this approach were chosen because they contain highly coarse-grained garnet (Grt) and orthopyroxene (Opx) porphyroblasts which have a high potential for preserving

Table 1. Mineral assemblages and chemical data

\begin{tabular}{|c|c|c|c|c|c|c|c|c|}
\hline Sample & Assemblage & Grt $X_{M g}$ & Opx $X_{M g}$ & $\mathrm{Al}_{2} \mathrm{O}_{3}$ & Spr $X_{M g}$ & Spl $X_{M g}$ & $\operatorname{Crd} \mathrm{X}_{\mathrm{Mg}}$ & Bt $X_{M g}$ \\
\hline \multirow[t]{3}{*}{ G-03 } & Sapphirine granulite & 0.48 & 0.67 & 9.65 & & & & \\
\hline & Spr-Qtz inclusions in Grt & & & & 0.85 & & & \\
\hline & $\mathrm{Bt}+\mathrm{Qtz}+\mathrm{Crn}+\mathrm{Pl}$ inclusions in Grt & & & & & & & 0.82 \\
\hline \multirow[t]{5}{*}{ G-05 } & Sapphirine granulite & 0.48 & 0.65 & 9.72 & & & & \\
\hline & Spr in Sil in Grt & & & & 0.82 & & & \\
\hline & Spl inclusions in Grt & & & & & 0.51 & & \\
\hline & Spr + Qtz in Grt & & & & & & & \\
\hline & $\mathrm{Bt}-\mathrm{Qtz}-\mathrm{Crn}$ in Grt & & & & 0.82 & & & 0.8 \\
\hline \multirow[t]{4}{*}{ G-07 } & Sapphirine granulite & 0.49 & 0.68 & 10.12 & & & & \\
\hline & Spr with Spl + Qtz, Sil inclusions & & & & 0.83 & & & \\
\hline & $\mathrm{Spl}+\mathrm{Qtz}$, Sil in Spr & & & & & 0.5 & & \\
\hline & $\mathrm{Spl}+\mathrm{Qtz}+\mathrm{Pl}$ inclusions in Grt & & & & & 0.5 & & \\
\hline \multirow[t]{2}{*}{ G-14A } & Grt-Opx granulite & & & & & & & \\
\hline & Grt-Opx porphyroblast & 0.50 & 0.65 & 8.16 & & & & \\
\hline \multirow[t]{2}{*}{ G-14B } & Grt-Opx granulite & & & & & & & \\
\hline & Grt-Opx porphyroblast & 0.51 & 0.72 & 8.17 & & & & \\
\hline \multirow[t]{3}{*}{ G-06 } & Sapphirine granulite & 0.46 & 0.71 & 8.17 & & & 0.88 & \\
\hline & Spr-Qtz discrete grains & & & & 0.73 & & & \\
\hline & Spr-Sil inclusions in Qfs domains & & & & 0.73 & & & \\
\hline \multirow[t]{3}{*}{ G-09 } & Sapphirine granulite & 0.49 & 0.71 & 8.75 & & & 0.88 & \\
\hline & Spr-Qtz discrete grains & & & & 0.79 & & & \\
\hline & Opx-Sil porphyroblast & & & & & & & \\
\hline \multirow[t]{5}{*}{ G-12 } & Sapphirine granulite & 0.45 & 0.72 & 8.72 & 0.75 & & & \\
\hline & Opx-Sil intergrowths & & & & & & & \\
\hline & Crd moats & & & & & & 0.89 & \\
\hline & Bt replacing Grt & & & & & & & 0.80 \\
\hline & Bt coronas on Grt & & & & & & & 0.78 \\
\hline
\end{tabular}


Table 2. Representative electron microprobe analyses of sapphirine from G. Madugala

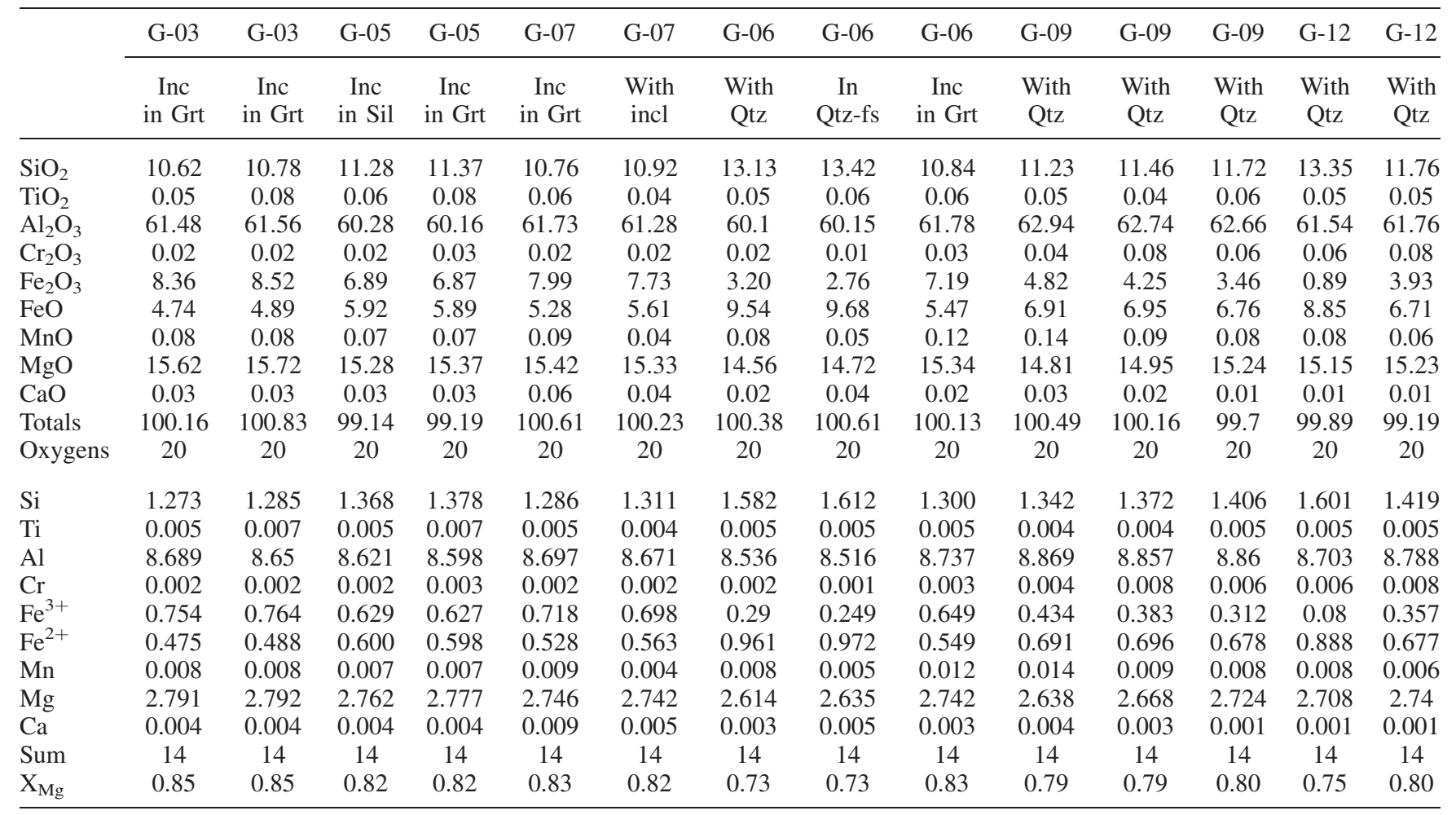

Table 3. Representative spinel analysis

\begin{tabular}{|c|c|c|c|c|c|c|c|c|c|c|}
\hline Sample & G-05 & G-05 & G-07 & G-07 & G-06 & G-06 & G-09 & G-09 & G-12 & G-12 \\
\hline Location & Core & Rim & Core & Rim & Core & Rim & Core & Rim & Core & Rim \\
\hline $\mathrm{SiO}_{2}$ & 0.06 & 0.07 & 0.02 & 0.03 & 0.04 & 0.02 & 1.62 & 0.03 & 0.02 & 0.03 \\
\hline $\mathrm{TiO}_{2}$ & 0.03 & 0.04 & 0.3 & 0.04 & 0.01 & 0.03 & 0.02 & 0.02 & 0.04 & 0.02 \\
\hline $\mathrm{Al}_{2} \mathrm{O}_{3}$ & 62.86 & 62.28 & 58.88 & 58.67 & 62.18 & 52.86 & 57.92 & 60.93 & 61.72 & 62.12 \\
\hline $\mathrm{Cr}_{2} \mathrm{O}_{3}$ & 0.18 & 0.09 & 0.06 & 0.05 & 0.19 & 0.06 & 0.04 & 0.22 & 0.1 & 0.28 \\
\hline $\mathrm{Fe}_{2} \mathrm{O}_{3}$ & 0.92 & 1.33 & 7.00 & 7.41 & 1.9 & 14.62 & 12.14 & 4.91 & 2.85 & 2.27 \\
\hline $\mathrm{FeO}$ & 21.95 & 21.66 & 22.25 & 22.11 & 22.61 & 20.77 & 16.38 & 20.44 & 23.35 & 23.78 \\
\hline $\mathrm{MnO}$ & 0.08 & 0.07 & 0.06 & 0.05 & 0.03 & 0.08 & 0.06 & 0.02 & 0.12 & 0.09 \\
\hline $\mathrm{MgO}$ & 12.88 & 12.92 & 12.87 & 12.72 & 12.47 & 12.96 & 12.35 & 13.96 & 12.04 & 11.87 \\
\hline Totals & 98.96 & 98.46 & 101.44 & 101.08 & 99.25 & 99.94 & 100.54 & 100.05 & 99.97 & 100.24 \\
\hline Oxygens & 4 & 4 & 4 & 4 & 4 & 4 & 4 & 4 & 4 & 4 \\
\hline $\mathrm{Si}$ & 0.002 & 0.002 & 0.001 & 0.001 & 0.001 & 0.001 & 0.321 & 0.001 & 0.001 & 0.001 \\
\hline $\mathrm{Ti}$ & 0.001 & 0.001 & 0.006 & 0.001 & 0.000 & 0.001 & 0.003 & 0.000 & 0.001 & 0.000 \\
\hline $\mathrm{Al}$ & 1.974 & 1.966 & 1.846 & 1.847 & 1.956 & 1.697 & 13.513 & 1.896 & 1.938 & 1.947 \\
\hline $\mathrm{Cr}$ & 0.004 & 0.002 & 0.001 & 0.001 & 0.004 & 0.001 & 0.006 & 0.005 & 0.002 & 0.006 \\
\hline $\mathrm{Fe}^{3+}$ & 0.018 & 0.027 & 0.14 & 0.149 & 0.038 & 0.299 & 1.807 & 0.097 & 0.057 & 0.045 \\
\hline $\mathrm{Fe}^{2+}$ & 0.489 & 0.485 & 0.495 & 0.494 & 0.505 & 0.473 & 2.711 & 0.452 & 0.521 & 0.529 \\
\hline $\mathrm{Mn}$ & 0.002 & 0.002 & 0.001 & 0.001 & 0.001 & 0.002 & 0.01 & 0.00 & 0.003 & 0.002 \\
\hline $\mathrm{Mg}$ & 0.511 & 0.516 & 0.510 & 0.506 & 0.496 & 0.526 & 3.642 & 0.549 & 0.478 & 0.470 \\
\hline Sum & 3 & 3 & 3 & 3 & 3 & 3 & 3 & 3 & 3 & 3 \\
\hline $\mathrm{X}_{\mathrm{Mg}}$ & 0.51 & 0.51 & 0.50 & 0.50 & 0.50 & 0.53 & 0.57 & 0.55 & 0.48 & 0.47 \\
\hline
\end{tabular}


SAPPHIRINE GRANULITES FROM SOUTHERN INDIA

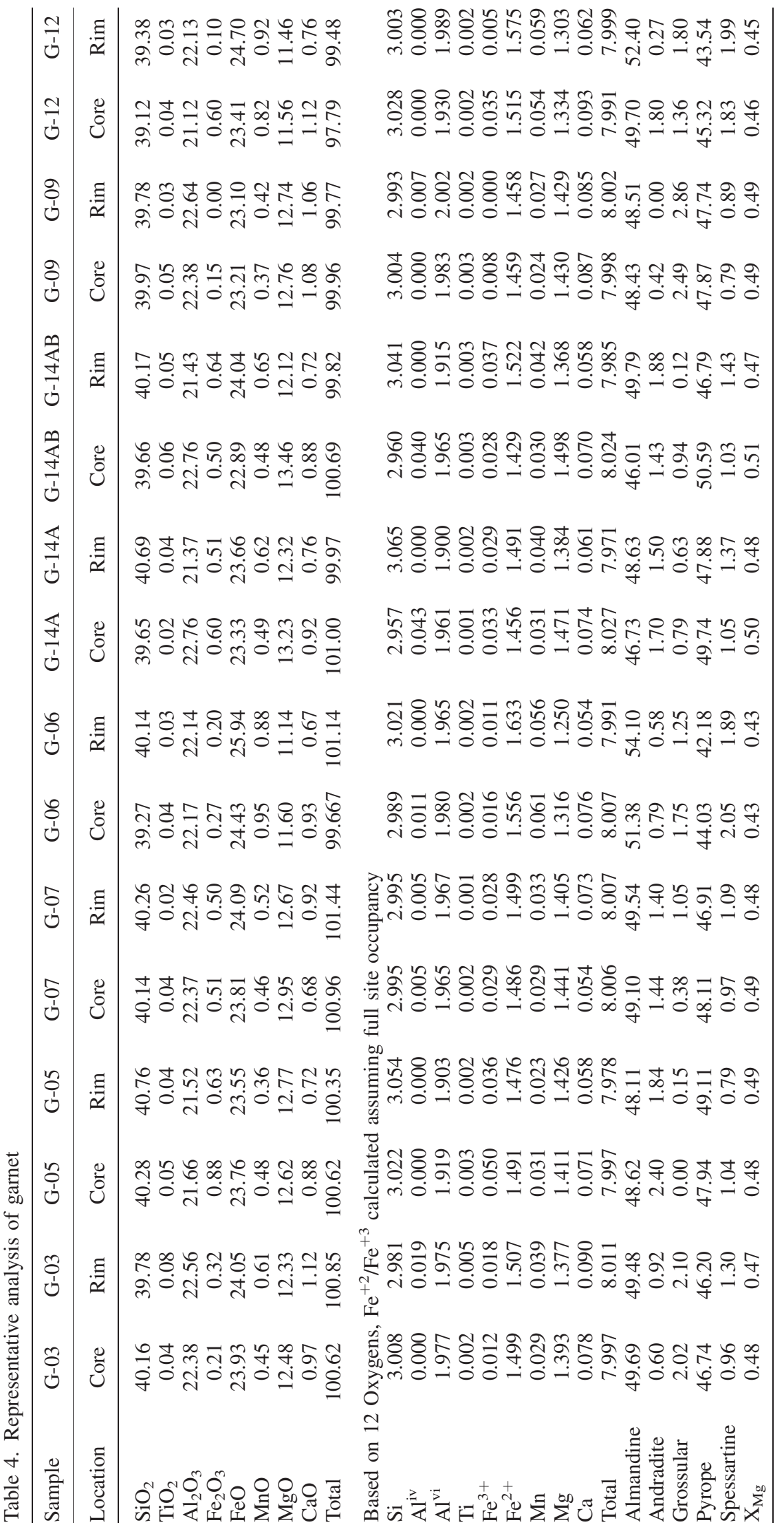


Table 5. Representative analysis of orthopyroxene

\begin{tabular}{|c|c|c|c|c|c|c|c|c|c|c|c|c|c|c|c|}
\hline \multirow[t]{2}{*}{ Sample } & G-03 & -05 & -05 & G-07 & -07 & -06 & -06 & $-14 \mathrm{~A}$ & $-14 \mathrm{~A}$ & $-14 \mathrm{AB}$ & $\mathrm{s}-14 \mathrm{AB}$ & j-09 & G-09 & G-12 & $\mathrm{J}-12$ \\
\hline & Core & Core & & $\mathrm{S}_{0}$ & & A. & & & & & & Core & & & D. \\
\hline & & & & & & & & & & & & 48.22 & & & 48.12 \\
\hline & & & & & & & & & & & & & & & 0.09 \\
\hline${ }_{2} \mathrm{O}_{3}$ & 9 & & & 10.12 & & & & & 0. & & 7 & 8.75 & & & 8.56 \\
\hline $\mathrm{r}_{2} \mathrm{O}_{3}$ & 02 & & & 0.06 & 0 . & & 04 & 0.04 & 0.0 & & 0.07 & 0.04 & 0.03 & & 0.04 \\
\hline${ }_{2} \mathrm{O}_{3}$ & 2.79 & 0.91 & & 2.3 & 2.63 & & 3.83 & 1.85 & 7.0 & & 6.86 & 3.15 & 3.8 & & 2.99 \\
\hline & 18.25 & 20.74 & 20.88 & 17.15 & 17.19 & & 16.15 & 20.11 & & & & & & & 17.2 \\
\hline & & & & & & & & & & & & & & & 0.12 \\
\hline 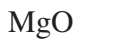 & & 6 & 2 & & & & & & & & & & & & 22.96 \\
\hline & & & & & & & & & & & & & & & 0.08 \\
\hline Tot & & & 100.8 & & & & & & & & & & & & 100.46 \\
\hline & 6 & & & & & & & & & & & & & & 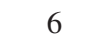 \\
\hline & & & & & & & & & & & & & & & \\
\hline & 3 & & c & & & & & & & & & & & & 02 \\
\hline 11 & 8 & & & & & & & & & & & & & & .367 \\
\hline $\mathrm{Cr}$ & 001 & 001 & 001 & 0.002 & 0.001 & & 0.001 & 0.001 & & & 0.0 & 0.001 & 0.001 & & 0.001 \\
\hline & 0.077 & 0.025 & 0.025 & & & 7007 & 0.105 & 0.052 & 0.193 & & & 0.087 & 0.105 & & 0.082 \\
\hline $\mathrm{Fe}^{2+}$ & & (6) & - & & & & & & & & & & & & 0.523 \\
\hline & & & & & & & & & & & & & & & .004 \\
\hline & & & & & & & & & & & & & & & .245 \\
\hline & & & & & & & & & & & & & & & \\
\hline & & & & & & & & & & & & & & & 4.000 \\
\hline $\mathrm{X}_{\mathrm{Mg}}$ & & & & & & & & & & & & 0.71 & & & 0.70 \\
\hline $\mathrm{Y}_{\mathrm{Mg}}$ & 0.167 & 0.169 & 0.167 & 0.193 & 0.169 & 0.122 & 0.118 & 0.152 & 0.043 & 0.102 & 0.054 & 0.142 & 0.125 & 0.125 & 0.139 \\
\hline
\end{tabular}

mineral chemical evidence for UHT conditions. This region is one of the few documented terranes for which such calculations are possible. Other such areas include the GrtOpx gneiss of the Mather Peninsula, Antarctica (Harley, 1998a) and the Grt-Opx granulites from the Epupa Complex, Namibia (Brandt et al., 2003). Locations lacking the coarse-grained assemblages do not permit direct calculation of UHT conditions via conventional geothermobarometry because of post-peak diffusional $\mathrm{Fe}-\mathrm{Mg}$ exchange (e.g. Frost and Chacko, 1989; Harley, 1998b). Unless otherwise specified, the stoichiometric calculations of analysed minerals used in the geothermobarometric estimates were performed with the program AX (Holland and Powell, 1998 available at http://www.esc.cam.ac.uk/ astaff/holland/index.html).

The second approach used to estimate $P-T$ conditions was the preparation of isochemical sections for sapphirinebearing granulites. Such isochemical sections are powerful in that they allow additional constraints on the $P-T-X$ evolution that cannot necessarily be deduced from thermobarometric calculations. The use of isochemical sections to evaluate the stability of mineral assemblages and evolution from one assemblage to another has become increasingly common (e.g. White et al., 2001; White and Powell, 2002; Johnson et al., 2003a, 2003b; Kelsey et al., 2003a, 2003b; Zeh and Holness, 2003; Johnson and Brown, 2004; Saha et al., 2008; Nasipuri et al., 2009; Lopez-Carmona et al.,
2010). A critical consideration in the calculation of these isochemical sections is the estimation of an appropriate bulk chemical composition, which must take into account the equilibration volume of the mineral assemblage observed in thin section. For medium- to high-grade rocks, a representative bulk composition is commonly estimated using molecular proportions recalculated from X-ray fluorescence (XRF) analyses (e.g. Kelsey et al., 2005). This method has been applied in the present study. Estimating the absolute amount of water in each bulk composition is problematic. Since biotite and cordierite, the only hydrous phases observed in these samples, are interpreted to be confined to retrograde assemblage, the amount of water present in the bulk composition during peak metamorphism would have been low. The loss on ignition (LOI) content obtained for these samples has been taken to represent $\mathrm{H}_{2} \mathrm{O} . \mathrm{Fe}^{3+}$ was estimated by recalculating mineral analysis to incorporate $\mathrm{Fe}^{3+}$.

The isochemical sections have been calculated in the system $\mathrm{Na}_{2} \mathrm{O}-\mathrm{CaO}-\mathrm{K}_{2} \mathrm{O}-\mathrm{FeO}-\mathrm{MgO}-\mathrm{Al}_{2} \mathrm{O}_{3}-\mathrm{SiO}_{2}-\mathrm{H}_{2} \mathrm{O}-$ $\mathrm{TiO}_{2}-\mathrm{Fe}_{2} \mathrm{O}_{3}$ (NCKFMASHTO). This system was chosen for the isochemical sections because most calculations of melting processes in metapelitic compositions can be adequately modelled in this system (White and Powell, 2002). Isochemical sections for the $P-T$ range $600-1000^{\circ} \mathrm{C}$ and 4-11 kbars were computed using the software Perple_X (Connolly, 2005) for the bulk compositions of the samples shown in Table 7. The following phases and the corresponding 
Table 6. Representative analysis of cordierite and biotite

\begin{tabular}{|c|c|c|c|c|c|c|c|}
\hline Sample & G-06 & G-09 & G-12 & G-03 & G-05 & G-14A & G-12 \\
\hline Min & Crd & Crd & Crd & $\mathrm{Bt}$ & $\mathrm{Bt}$ & $\mathrm{Bt}$ & $\mathrm{Bt}$ \\
\hline $\mathrm{SiO}_{2}$ & 49.73 & 49.67 & 49.34 & 39.78 & 39.42 & 39.66 & 39.82 \\
\hline $\mathrm{TiO}_{2}$ & 0.01 & 0.02 & 0.04 & 4.28 & 4.34 & 4.38 & 4.42 \\
\hline $\mathrm{Al}_{2} \mathrm{O}_{3}$ & 33.2 & 33.43 & 33.78 & 14.2 & 13.07 & 12.74 & 12.86 \\
\hline $\mathrm{Cr}_{2} \mathrm{O}_{3}$ & 0.00 & 0.00 & 0.02 & 0.03 & 0.02 & 0.02 & 0.04 \\
\hline $\mathrm{Fe}_{2} \mathrm{O}_{3}$ & 0.8 & 0.73 & 0.68 & 0.93 & 0.00 & 0.00 & 0.00 \\
\hline $\mathrm{FeO}$ & 2.88 & 2.62 & 2.46 & 6.76 & 7.86 & 8.86 & 9.32 \\
\hline $\mathrm{MnO}$ & 0.05 & 0.04 & 0.04 & 0.00 & 0.00 & 0.00 & 0.00 \\
\hline $\mathrm{MgO}$ & 12.62 & 11.87 & 12.15 & 21.65 & 20.65 & 20.12 & 19.42 \\
\hline $\mathrm{CaO}$ & 0.03 & 0.06 & 0.03 & 0.08 & 0.04 & 0.02 & 0.01 \\
\hline $\mathrm{Na}_{2} \mathrm{O}$ & 0.00 & 0.00 & 0.00 & 0.12 & 0.18 & 0.12 & 0.08 \\
\hline $\mathrm{K}_{2} \mathrm{O}$ & 0.00 & 0.00 & 0.00 & 10.22 & 10.46 & 10.88 & 10.14 \\
\hline Totals & 99.32 & 98.43 & 98.55 & 97.97 & 96.05 & 96.81 & 96.12 \\
\hline Oxygens & 18 & 18 & 18 & 11 & 11 & 11 & 11 \\
\hline $\mathrm{Si}$ & 4.963 & 4.987 & 4.948 & 2.790 & 2.839 & 2.853 & 2.875 \\
\hline $\mathrm{Ti}$ & 0.001 & 0.002 & 0.003 & 0.226 & 0.235 & 0.237 & 0.240 \\
\hline $\mathrm{Al}$ & 3.906 & 3.957 & 3.993 & 1.174 & 1.110 & 1.080 & 1.095 \\
\hline $\mathrm{Cr}$ & 0.000 & 0.000 & 0.002 & 0.002 & 0.001 & 0.001 & 0.002 \\
\hline $\mathrm{Fe}^{3+}$ & 0.060 & 0.055 & 0.052 & 0.050 & 0.000 & 0.000 & 0.000 \\
\hline $\mathrm{Fe}^{2+}$ & 0.240 & 0.220 & 0.207 & 0.396 & 0.473 & 0.533 & 0.563 \\
\hline $\mathrm{Mn}$ & 0.004 & 0.003 & 0.003 & 0.000 & 0.000 & 0.000 & 0.000 \\
\hline $\mathrm{Mg}$ & 1.877 & 1.776 & 1.816 & 2.263 & 2.216 & 2.157 & 2.089 \\
\hline $\mathrm{Ca}$ & 0.003 & 0.006 & 0.003 & 0.006 & 0.003 & 0.002 & 0.001 \\
\hline $\mathrm{Na}$ & 0.000 & 0.000 & 0.000 & 0.016 & 0.025 & 0.017 & 0.011 \\
\hline K & 0.000 & 0.000 & 0.000 & 0.914 & 0.961 & 0.998 & 0.934 \\
\hline Sum & 11.054 & 11.006 & 11.026 & 7.838 & 7.864 & 7.878 & 7.810 \\
\hline$X_{M g}$ & 0.88 & 0.88 & 0.89 & 0.85 & 0.82 & 0.80 & 0.78 \\
\hline
\end{tabular}

phase components were used (abbreviations as per the program), Sapphirine [spr7, fspr], corderite [crd, fcrd, hcrd, hfcrd], Crn, Spl [spl, herc], orthopyroxene [en, fs, mgts], biotite [ann, phl, east], Kfs, Sill, Qtz and silicate melt phase [h2OL, fo8L, fa8L, sil8L, kspL]. Sillimanite and quartz were taken to be pure phases. The solution models (details in solut09.dat; PERPLEX 07; database: hp04ver.dat) adopted are Opx (HP), Sp (HP), Sapp (HP), Bio(HP), hCrd and Melt (HP). For hydrous fluids, the solution model of Kerrick and Jacobs (1981) was adopted. The solid solution models (Powell et al., 1998) being compatible with this dataset were selected from the downloaded version of the PERPLEX solution model file (solut09.dat). Table 8 indicates the general formula and references for each solution model used. The obtained graphical results (subprograms vertex and psvdraw) were taken as raw data and the final diagrams were redrawn by smoothing curves as demonstrated by Connolly (2005).

\section{RESULTS}

\subsection{Petrography}

The study area is primarily composed of metapelitic granulites, orthopyroxene granulites, high $\mathrm{Mg}-\mathrm{Al}$ granulites, charnockite enderbites and leptynites. Orthopyroxene

Table 7. Mol\% of whole rock bulk compositions

\begin{tabular}{|c|c|c|c|c|}
\hline Sample & G-5 & G-6 & G-14A & G-9 \\
\hline $\mathrm{Na}_{2} \mathrm{O}$ & 0.52 & 0.58 & 0.54 & 0.52 \\
\hline $\mathrm{MgO}$ & 15.92 & 15.86 & 42.01 & 39.20 \\
\hline $\mathrm{Al}_{2} \mathrm{O}$ & 18.44 & 18.66 & 8.59 & 9.63 \\
\hline $\mathrm{K}_{2} \mathrm{O}$ & 0.96 & 0.72 & 1.37 & 1.75 \\
\hline $\mathrm{CaO}$ & 0.58 & 0.62 & 0.44 & 0.57 \\
\hline $\mathrm{FeO}$ & 8.36 & 8.72 & 3.46 & 4.33 \\
\hline $\mathrm{SiO}_{2}$ & 56.08 & 55.38 & 37.47 & 38.08 \\
\hline $\mathrm{H}_{2} \mathrm{O}$ & 0.12 & 0.14 & 6.12 & 5.92 \\
\hline Sum & 100.98 & 100.68 & 100.00 & 100.00 \\
\hline
\end{tabular}


Table 8. Solution notation, formulae and model sources used for isochemical sections

\begin{tabular}{llll}
\hline Symbol & Solution & Formula & Source \\
\hline $\mathrm{Bio}(\mathrm{HP})$ & Biotite & $\mathrm{K}\left[\mathrm{Mg}_{x} \mathrm{Fe}_{y} \mathrm{Mn}_{1-x-y}\right]_{3-w} \mathrm{Al}_{1+2 w} \mathrm{Si}_{3-w} \mathrm{O}_{10}(\mathrm{OH})_{2}, x+y \leq 1$ & Powell and Holland, 1999 \\
$\mathrm{Gt}(\mathrm{HP})$ & Garnet & $\mathrm{Fe}_{3 x} \mathrm{Ca}_{3 y} \mathrm{Mg}_{3 z} \mathrm{Mn}_{3(1-x-y-z} \mathrm{Al}_{2} \mathrm{Si}_{3} \mathrm{O}_{12}, x+y+z \leq 1$ & Holland and Powell, 1998 \\
hCrd & Cordierite & $\mathrm{Mg}_{2 x} \mathrm{Fe}_{2 y} \mathrm{Mn}_{2(1-x-y)} \mathrm{Al}_{4} \mathrm{Si}_{5} \mathrm{O}_{18} \bullet\left(\mathrm{H}_{2} \mathrm{O}\right)_{z}, x+y \leq 1$ & Thomson and Hovis, 1979 \\
Kf & Alkali feldspar & $\mathrm{Na}_{x} \mathrm{~K}_{1-x} \mathrm{AlSi}_{3} \mathrm{O}_{8}$ & Holland and Powell, 2001 \\
Melt(HP) & Melt & $\mathrm{Na}_{-} \mathrm{Mg}_{-}-\mathrm{Al}_{-} \mathrm{Si}_{-} \mathrm{K}-\mathrm{Ca}-\mathrm{Fe}$ hydrous silicate melt & Ideal \\
Sp(HP) & Spinel & $\mathrm{Mg}_{x} \mathrm{Fe}_{1-x} \mathrm{Al}_{2} \mathrm{O}_{3}$ & Ideal \\
Spr & Sapphirine & $\mathrm{Mg}_{3.5} \mathrm{Al}_{9} \mathrm{Si}_{1.5} \mathrm{O}_{20}$ & Holland and Powell, 1996 \\
Opx(HP) & Orthopyroxene & {$\left[\mathrm{Mg}_{x} \mathrm{Fe}_{1-x}\right]_{2-y} \mathrm{Al}_{2 y} \mathrm{Si}_{2-y} \mathrm{O}_{6}$} & \\
\hline
\end{tabular}

granulites (northeast of G. Madugula) in the EGB occur as tens of metres wide layers and boudins within regionally extensive garnet-sillimanite-bearing pelitic granulites. The rocks show prominent compositional domains with garnetsillimanite \pm cordierite \pm spinel-rich melanosome domains and quartzo-feldspathic leucosome domains. The sapphirine-bearing high $\mathrm{Mg}-\mathrm{Al}$ granulites occur as enclaves hosted in the granulite facies charnockites.

The sapphirine granulites contain sapphirine, orthopyroxene, biotite, sillimanite, cordierite, garnet, spinel, quartz, corundum and K-feldspar in a variety of associations. Minor amounts of rutile, ilmenite and apatite are also present. Some assemblages are characterized by the stable association of sapphirine + quartz, spinel + quartz and sillimanite + orthopyroxene + quartz. Mineral inclusions are attrib- uted to the prograde evolution, porphyroblasts to the peak stages of metamorphism and the well-preserved reaction textures to the retrograde evolution. A brief description of the petrography of different types of granulites is given below. Representative assemblages and chemical data are summarized in Table 1; and salient textural features are shown in Figures 2-5.

\subsubsection{Sapphirine-bearing granulite (samples \# G-03, G-05, G-07)}

The sapphirine granulites contain sapphirine, orthopyroxene, biotite, sillimanite, garnet, spinel, quartz, biotite, corundum and K-feldspar in a variety of associations. The assemblage sapphirine + quartz occurs as isolated inclusions in porphyroblastic garnet (Figure 2a). Porphyroblastic garnet in the same
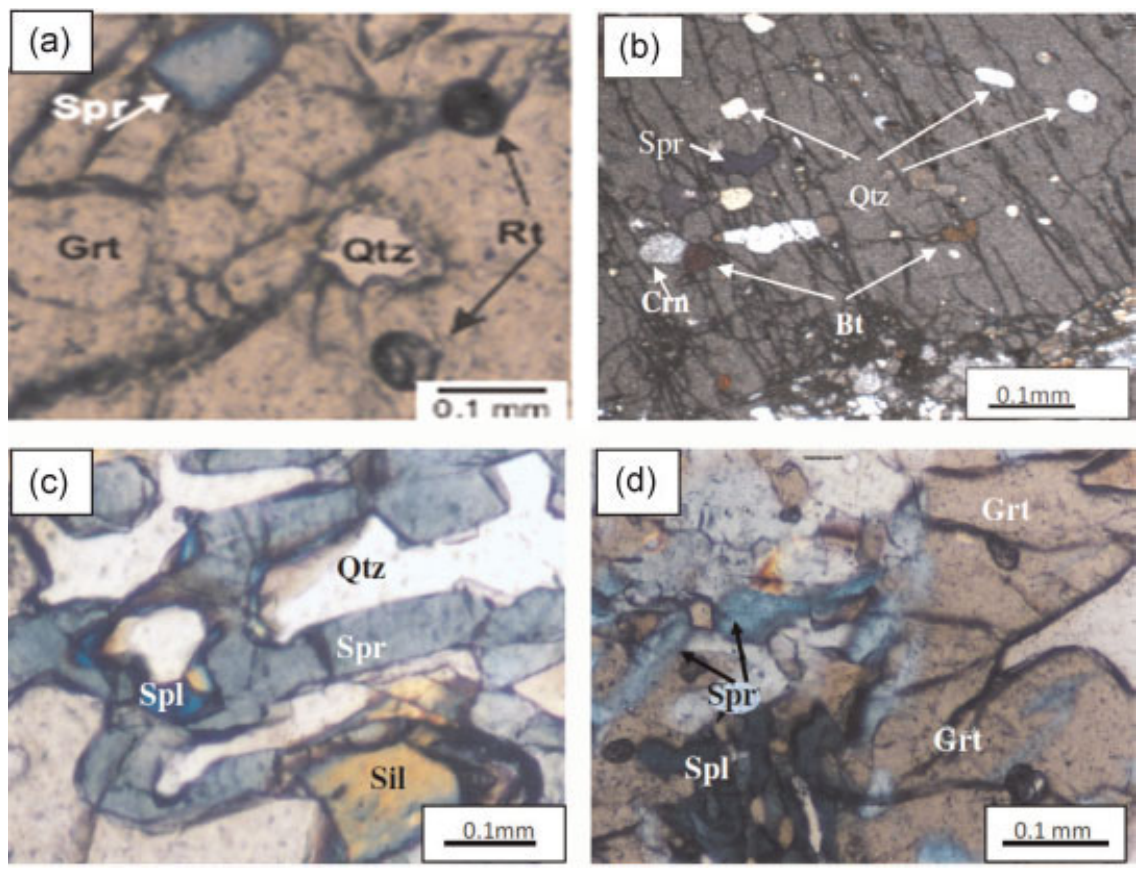

Figure 2. Thin section photomicrographs of sapphirine-bearing granulite in open nicols (samples \# G-03, G-05, G-07). (a) Isolated inclusions of sapphirine (Spr) along with quartz (Qtz) in porphyroblast garnet (Grt) within the melanocratic domains of the sapphirine granulite. (b) Subrounded biotite, cuspate quartz and sub-rounded sapphirine, corundum $(\mathrm{Cm})$ inclusions in porphyroblast garnet in sapphirine granulite. (c) Dark blue subhedral spinel (Spl) inclusions within sapphirine in garnet-rich layer. Note the intergrowth of quartz within sapphirine. (d) Sapphirine along with spinel, cuspate quartz within the porphyroblast garnet. This figure is available in colour online at wileyonlinelibrary.com/journal/gj. 

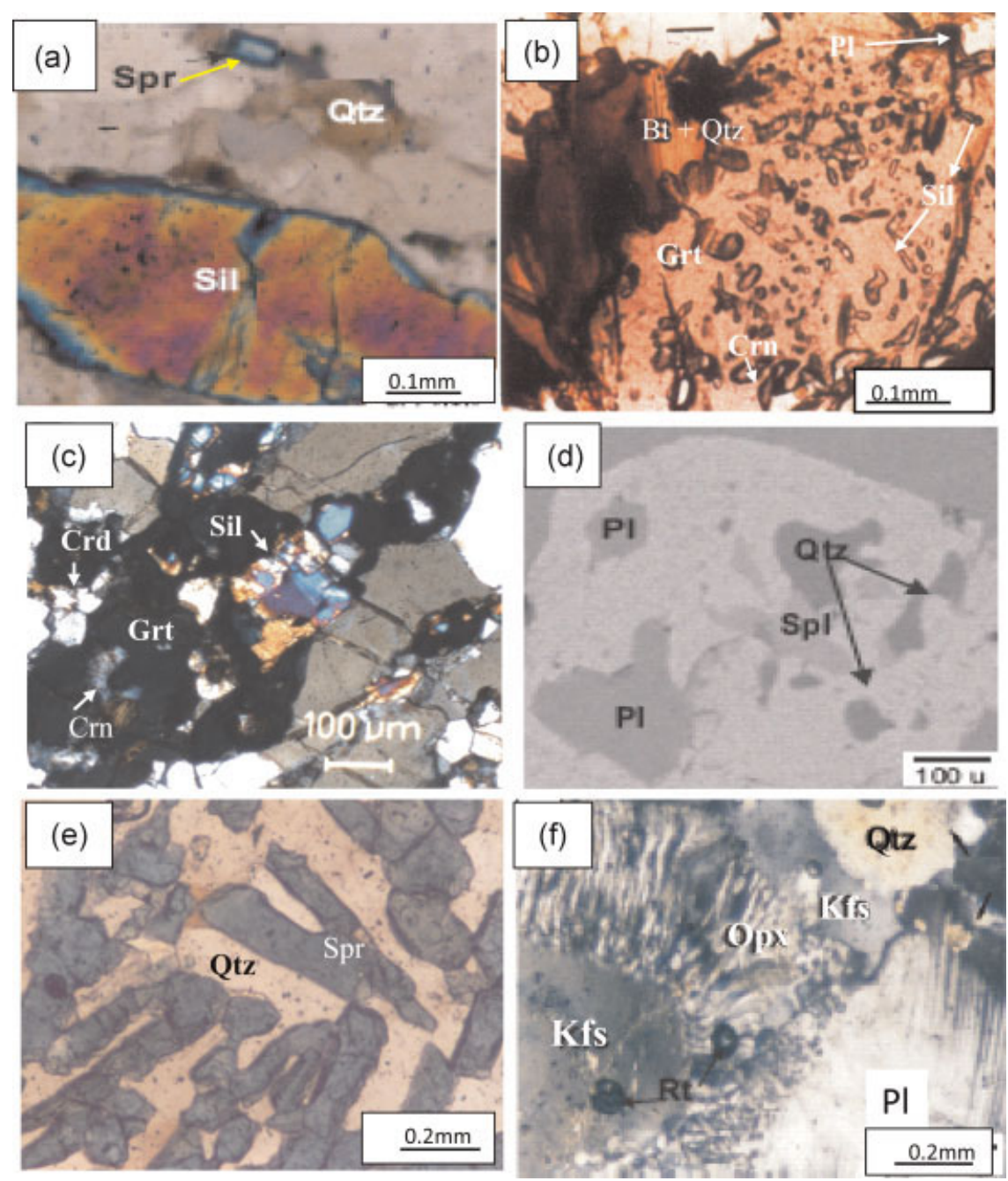

Figure 3. Thin section photomicrographs of migmatitic sapphirine granulite in open nicols (sample \# G-06) (a) Large relict sillimanite and small sapphirinequartz in the quartzo-feldspathic domain in sapphirine granulite. (b) Garnet porphyroblast studded with inclusions of sillimanite (Sil), biotite (Bt), plagioclase (Pl) and corundum. Note biotite + quartz replacing garnet margin on the left portion of garnet. (c) Garnet porphyroblast with inclusions of sillimanite, cordierite and corundum (in cross-polarized light). (d) Back-scattered image (BSE) of poikiloblastic garnet showing composite inclusions. Note the rounded shape of quartz and its association with minerals such as spinel (Spl) and plagioclase (Pl) in sapphirine granulite. (e) Sapphirine in contact with quartz in sapphirine granulite. (f) Plumose intergrowths of plagioclase-K-feldspar (Kfs) in sapphirine granulite. This figure is available in colour online at wileyonlinelibrary.com/ journal/gj.

domains also contains isolated inclusions of prismatic biotite, cuspate quartz, corundum and isolated inclusions of dark blue sapphirine (Figure 2b). In addition, there are textures with quartz grains intergrowing with sapphirine. Spinel also occurs as rare inclusions in sapphirine (Figure 2c). Sapphirine, quartz and sillimanite are only observed as inclusions within garnet. Sapphirine also occurs as loose masses along with quartz within the same porphyroblastic garnet (Figure 2d). Corundum occurs both as an inclusion and matrix phase. Composite inclusions of quartz, plagioclase, biotite and corundum in porphyroblast garnet also occur as matrix phases along with orthopyroxene. The assemblage preserved as inclusions within garnet (biotite-sillimanite-plagioclasequartz) has otherwise been overprinted by the coarse-grained peak-metamorphic assemblage of sapphirine-biotite-orthopyroxene. Distribution of minerals included within garnet porphyroblasts suggests that the observed assemblage is heterogeneous on a small scale; some parts are comprised of sapphirine-spinel while others contain plagioclase-quartzbiotite. The millimetre-scale modal heterogeneities were not completely homogenized during the growth of garnet, but are preserved as two distinct mineral assemblages in the scale of a thin section.

\subsubsection{Migmatitic sapphirine granulite (sample \# G-06)} Migmatitic sapphirine granulite occurs as small lenses along contacts between garnet-orthopyroxene granulites and pelitic granulites. It mainly consists of sapphirine, 

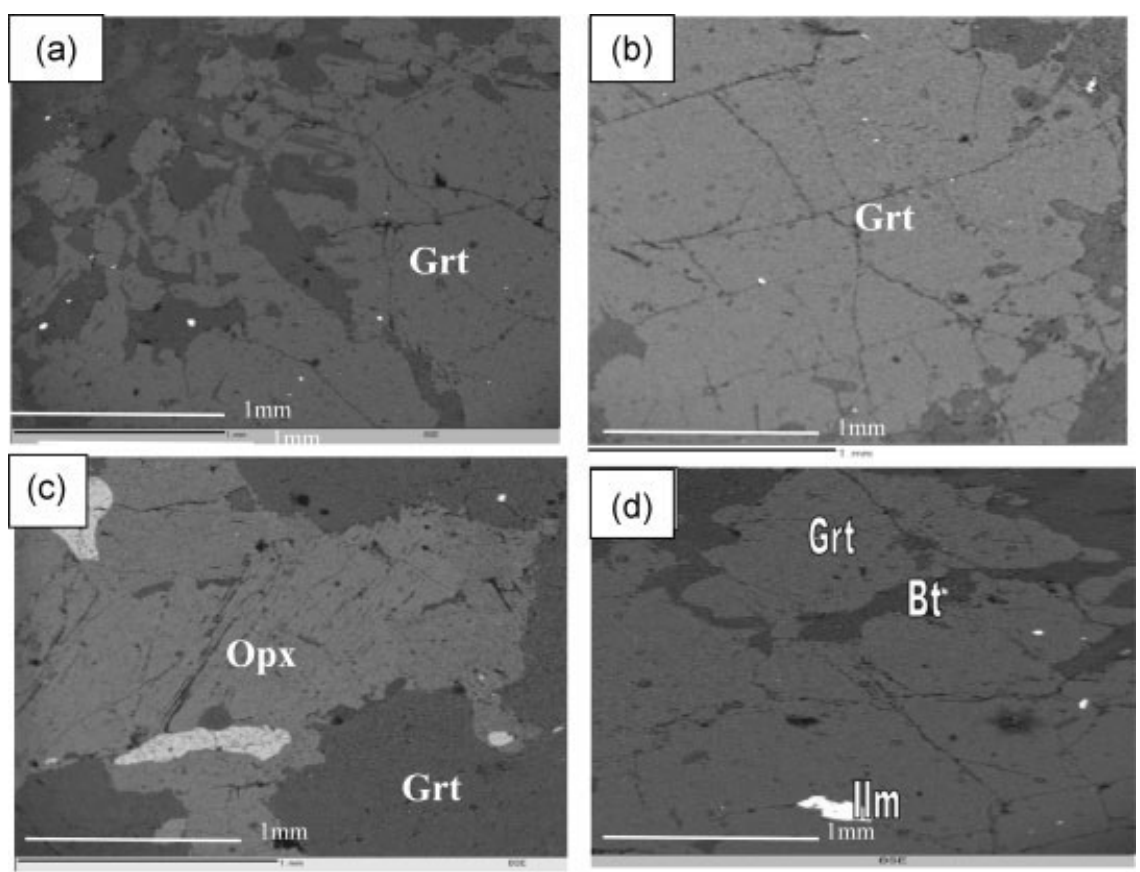

Figure 4. Back-scattered images of migmatitic garnet-orthopyroxene granulite (sample \# G-14/A, G-14AB) (a) Coarse garnet porphyroblast with inclusions of quartz and biotite in garnet orthopyroxene granulite. (b) Coarse inclusion-free garnet porphyroblast in garnet-orthopyroxene granulite. (c) Coarse-grained orthopyroxene and garnet. (d) Retrograde biotite (Bt) around garnet (Grt) in garnet-orthopyroxene granulite.
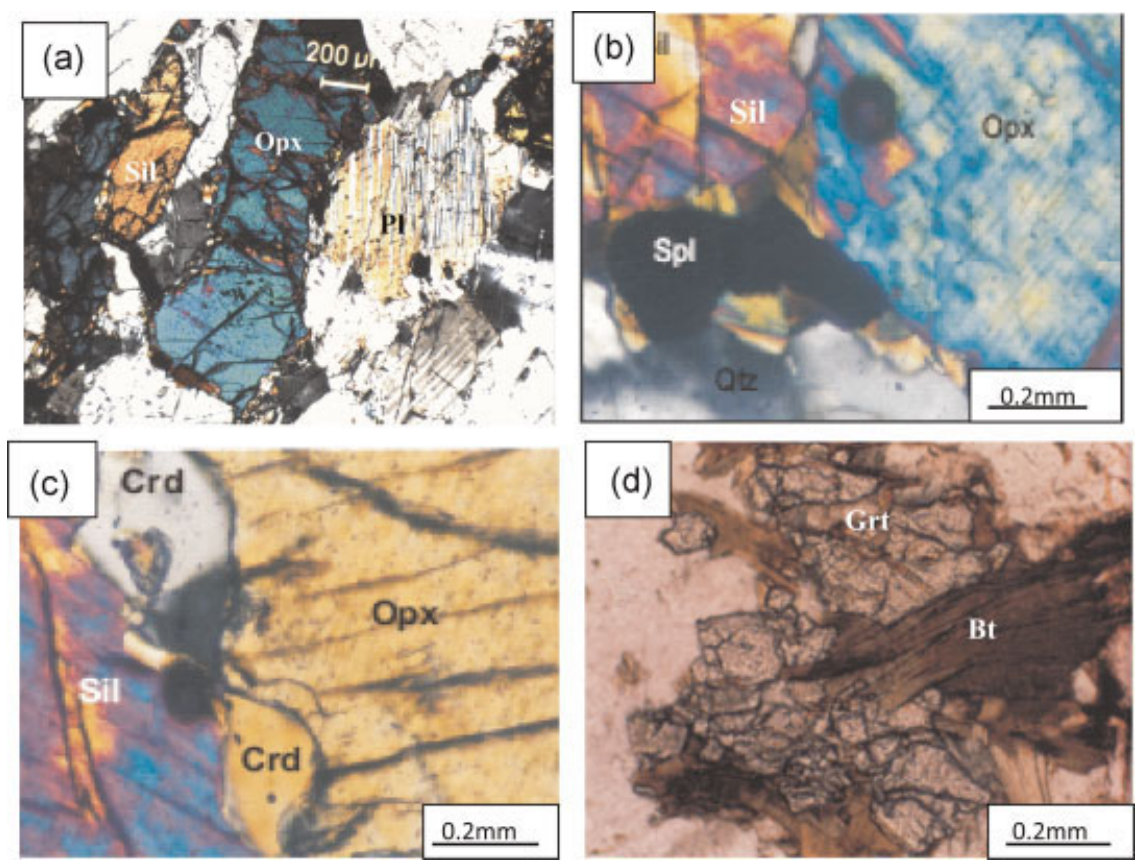

Figure 5. Thin section photomicrographs of garnet-orthopyroxene-sillimanite granulite (sample \# G-09) and orthopyroxene-sillimanite-cordierite granulite in crossed nicols (sample \# G-12) (a) Coarse-grained orthopyroxene and sillimanite occurring together with coarse plagioclase (Pl) in the matrix within the melanocratic portion. (b) Small quartz (Qtz) and lobate spinel (Spl) grains occurring together with orthopyroxene (Opx) and sillimanite (Sil). (c) Cordierite 'moats' (Crd) separating orthopyroxene-sillimanite aggregates. (d) Retrograde biotite (Bt) replacing inclusion-free garnet (Grt). This figure is available in colour online at wileyonlinelibrary.com/journal/gj. 
orthopyroxene, biotite, sillimanite, garnet, spinel, quartz, corundum, plagioclase and K-feldspar. A distinct gneissic texture is well developed and expressed by modal variations of the leucocratic and melanocratic layers.

Large relict sillimanite (Figure 3a) and small sapphirine grains occur within the leucocratic quartzo-feldspathic portions of the sample. Porphyroblastic garnet contains isolated inclusions of sapphirine and composite inclusions of quartz, plagioclase, biotite and spinel in leucocratic domains (Figure 3b,c). The composite inclusions contain about $25 \%$ quartz, which exhibits rounded shapes and is associated with spinel and plagioclase (Figure 3d). Sapphirine-biotiteorthopyroxene occurs as a stable assemblage within the melanocratic layers. This rock exhibits sharp contacts between sapphirine and quartz (Figure 3e). Plumose intergrowths of plagioclase and K-feldspar occur (Figure 3f). The generally migmatitic aspect of this sample indicates that it was once melt-bearing.

\subsubsection{Migmatitic garnet-orthopyroxene granulite (samples, \# G14A, G-14AB)}

The coarse-grained semipelitic granulites preserve a stable assemblage of garnet + orthopyroxene + quartz + plagioclase $\pm \mathrm{K}$-feldspar \pm biotite with minor amounts of ilmenite, rutile, zircon and rare apatite. The garnetorthopyroxene granulites show a characteristic migmatitic texture. The original compositional banding is modified by leucocratic layers which are commonly concordant to the compositional banding. These layers are composed of plagioclase, quartz and rare K-feldspar. The melanocratic layer is dominated by orthopyroxene and garnet. Garnet occurs as distinct porphyroblasts (Figure 4a,b) that are set in a granoblastic quartz-feldspar matrix. Garnet coexists with porphyroblastic orthopyroxene (Figure 4c) and the contacts between the two locally display straight grain boundaries. The garnet porphyroblasts are always surrounded by biotite laths (Figure 4d). Plagioclase in the matrix appears as isolated anhedral grains. The dominant Ti phase of the matrix is rutile, but minor ilmenite and apatite occur.

\subsubsection{Garnet-orthopyroxene-sillimanite granulite ( sample \# G-09)}

This rock is similar to the garnet-orthopyroxene granulite except that sillimanite also occurs as a discrete phase. Orthopyroxene is medium grained and shows intergrowth with sillimanite. Coarse-grained orthopyroxene and sillimanite occur together (Figure 5a). Small spinel grains also occur together with orthopyroxene and sillimanite (Figure 5b). Garnet is not closely associated with sillimanite. However, in the melanocratic portions porphyroblasts of garnet and orthopyroxene occur.

\subsubsection{Orthopyroxene-sillimanite-cordierite granulite (sample \# G-12)}

The orthopyroxene-sillimanite-cordierite granulite contains an assemblage of sapphirine, orthopyroxene, sillimanite, cordierite, garnet, quartz, biotite, corundum, plagioclase and $\mathrm{K}$-feldspar. Cordierite is observed between orthopyroxene-sillimanite aggregates (Figure 5c) forming 'moats'. Garnet is rare in the leucocratic portions but occurs along with orthopyroxene in melanocratic portions. In these rocks variable amounts of biotite occur as a replacement of garnet (Figure 5d). Spinel has not been observed in this sample. The dominant $\mathrm{Ti}$ phase of the matrix is rutile, ilmenite occurs as an accessory phase.

\subsection{Mineral chemistry}

\subsubsection{Sapphirine}

Normalized sapphirine analyses are presented in Table 2. The stoichiometric calculations assumed 20 oxygens, 14 cations and $\mathrm{Fe}^{3+}$. Sapphirines are markedly aluminous (up to $\left.62.94 \mathrm{wt} \% \mathrm{Al}_{2} \mathrm{O}_{3}\right)$ and fairly iron rich $(\sim 9.7 \mathrm{wt} \% \mathrm{FeO})$. Sapphirine inclusions in garnet in sample G-03 show the highest $\mathrm{X}_{\mathrm{Mg}}$ (0.85). Sapphirine inclusions in quartzofeldspathic domains show low $\mathrm{X}_{\mathrm{Mg}}$ (0.73). Sapphirine in equilibrium with quartz is comparatively Si-rich and Alpoor, e.g. sample G-06: (1.61 wt\% Si, $8.51 \mathrm{wt} \% \mathrm{Al})$. Sapphirine inclusions in garnet are higher in $\mathrm{Fe}_{2} \mathrm{O}_{3}(6.8$ to $8.5 \mathrm{wt} \%$ ) than are the discrete grains of sapphirine (0.89 to $7.7 \mathrm{wt} \%)$. Zn contents are below the detection limit.

\subsubsection{Spinel}

Normalized spinel analyses are presented in Table $3 . \mathrm{Fe}^{3+}$ was calculated by charge balance. Spinel is a solid solution of $\mathrm{Mg}$-spinel and hercynite $\left(\mathrm{X}_{\mathrm{Mg}}=0.47-0.57\right)$, occasionally with small amounts of $\mathrm{Cr}_{2} \mathrm{O}_{3}(0.04-0.19 \mathrm{wt} \%)$ and $\mathrm{MnO}$ $(0.02-0.12 \mathrm{wt} \%)$. Although spinel occurs as inclusions in garnet along with cordierite and in association with sapphirine, there is no significant compositional difference between the two modes. $\mathrm{Zn}$ contents are below the detection limit.

\subsubsection{Garnet}

Representative compositions of garnet are shown in Table 4, along with structural formulas calculated using the spreadsheet of Tindle and Webb (1994). Garnet is essentially a solid solution between pyrope (43.5-50.6 mol\%) and almandine (46.1-54.1 mol\%) with minor grossular $(<3 \mathrm{~mol} \%)$ and spessartine $(<2 \mathrm{~mol} \%)$ components. Porphyroblastic garnet with multiphase inclusions in samples G-03, G-05 and G-07 shows nearly homogeneous compositions. However, the rim portions of retrograde garnets surrounded by biotite (sample G-12) show an increase in 
almandine at the rims (from $\mathrm{Alm}_{49.7}$ in the core to $\mathrm{Alm}_{52.5}$ in the rim).

\subsubsection{Orthopyroxene}

Normalized orthopyroxene analyses are presented in Table $5 . \mathrm{Fe}^{3+}$ was calculated by charge balance. Orthopyroxene shows marked compositional variation, depending on the mineral association. Orthopyroxene adjacent to garnet in the matrix in sample G-07 shows the highest $\mathrm{Al}_{2} \mathrm{O}_{3}$ content of up to $10.12 \mathrm{wt} \%(\mathrm{Al}=0.43 \mathrm{pfu})$. There is a systematic decrease in $\mathrm{Al}_{2} \mathrm{O}_{3}$ from core to rim (Table 5). $\mathrm{X}_{\mathrm{Mg}}$ ratios of all the analysed orthopyroxenes are reasonably consistent, showing a range of 0.65-72 despite the variations in $\mathrm{Al}_{2} \mathrm{O}_{3}$ contents. Such variation and high aluminum content were reported in other granulite facies rocks from the EGB (Lal et al., 1987; Sengupta et al., 1990; Bhattacharya and Kar, 2002) and are interpreted as a typical feature of UHT granulites (Harley, 1998a, 1998b). The high aluminum in the homogeneous core could reflect growth of the orthopyroxene during metamorphic peak conditions, whereas the low content of aluminum in the rims could reflect its growth during cooling immediately post-peak. Orthopyroxene in the garnet-orthopyroxene granulite (sample G-14) and sapphirine granulite (sample G-12) with highly refractory assemblage has the highest magnesium composition $\left(\mathrm{X}_{\mathrm{Mg}}=0.72\right)$. The lowest magnesium composition $\left(\mathrm{X}_{\mathrm{Mg}}=0.65\right)$ is in the sapphirine granulite with composite inclusions (sample G-05).

\subsubsection{Cordierite}

Cordierite shows a uniformly higher magnesian composition (0.88-0.89) than the coexisting phases with $\mathrm{X}_{\mathrm{Mg}}$ (Table 6). In this phase no core to rim variations were detected. The low analytical totals of cordierite suggest the presence of channel-filling volatiles, such as $\mathrm{CO}_{2}$ and/or $\mathrm{H}_{2} \mathrm{O}$, trapped in their crystal structure (Armbruster and Bloss, 1980).

\subsubsection{Biotite}

Biotite inclusions within garnet in sample G-03 shows the highest $\mathrm{Mg}$ content $\left(\mathrm{X}_{\mathrm{Mg}}=0.85\right)$ and the lowest Ti content $\left(\mathrm{TiO}_{2}=4.2 \mathrm{wt} \%\right.$, Table 6). Retrograde biotite has reasonably consistent $\mathrm{X}_{\mathrm{Mg}}(0.78-0.82)$ and $\mathrm{TiO}_{2}$ content of 4.3$4.4 \mathrm{wt} \%$ throughout the analysed samples.

\subsubsection{Other minerals}

$\mathrm{K}$-feldspar and plagioclase are dominant minerals in the quartzo-feldspathic domains of these rocks. K-feldspar is rich orthoclase and plagioclase ranges in composition from $\mathrm{An}_{45}-\mathrm{An}_{50}$ (Table 9). In corundum and sillimanite, the only impurity is iron, with $>1.06 \mathrm{wt} \% \mathrm{Fe}_{2} \mathrm{O}_{3}$ in corundum and $0.86-1.07 \mathrm{wt} \% \mathrm{Fe}_{2} \mathrm{O}_{3}$ in sillimanite.

Table 9. Representative analysis of sillimanite, corundum and feldspars

\begin{tabular}{|c|c|c|c|c|c|c|c|c|c|c|c|c|c|}
\hline Sample \# & G-09 & G-12 & G-12 & G-09 & G-12 & & G-09 & G-12 & G-06 & G-14A & G-14A & G-14AB & G-14AB \\
\hline Mineral & Sil & Sil & Crn & Kfs & Kfs & \multicolumn{8}{|c|}{ Plagioclase feldspar } \\
\hline \multirow[t]{2}{*}{ Location } & $\begin{array}{l}\text { Inc } \\
\text { in Grt }\end{array}$ & Matrix & $\begin{array}{l}\text { Inc } \\
\text { in Grt }\end{array}$ & $\begin{array}{l}\text { Inc } \\
\text { in Grt }\end{array}$ & $\begin{array}{l}\text { Inc } \\
\text { in Grt }\end{array}$ & & $\begin{array}{l}\text { Inc } \\
\text { in Grt }\end{array}$ & $\begin{array}{l}\text { Inc } \\
\text { in Grt }\end{array}$ & Inc & Matrix & Matrix & Matrix & Matrix \\
\hline & Core & Core & Core & Core & Core & & Core & Core & Core & Core & Rim & Core & Rim \\
\hline $\mathrm{SiO}_{2}$ & 36.98 & 36.92 & 0.08 & 64.17 & 64.88 & $\mathrm{SiO}_{2}$ & 57.77 & 57.86 & 46.76 & 57.86 & 58.92 & 59.08 & 58.97 \\
\hline $\mathrm{TiO}_{2}$ & & & & & & $\mathrm{Al}_{2} \mathrm{O}_{3}$ & 27.22 & 27.12 & 34.38 & 26.56 & 25.85 & 25.32 & 26.21 \\
\hline $\mathrm{Al}_{2} \mathrm{O}_{3}$ & 61.8 & 62.17 & 100.12 & 18.28 & 18.82 & $\mathrm{CaO}$ & 9.88 & 9.36 & 18.92 & 8.24 & 7.66 & 7.75 & 8.25 \\
\hline $\mathrm{Fe}_{2} \mathrm{O}_{3}$ & 1.07 & 0.86 & & & & $\mathrm{Na}_{2} \mathrm{O}$ & 6.12 & 6.86 & 1.12 & 6.72 & 7.32 & 7.45 & 7.28 \\
\hline $\mathrm{FeO}$ & 0 & 0 & 1.06 & & & $\mathrm{~K}_{2} \mathrm{O}$ & 0.28 & 0.36 & 0.06 & 0.27 & 0.32 & 0.06 & 0.05 \\
\hline $\mathrm{MnO}$ & 0 & 0 & 0.04 & & & total & 101.27 & 101.20 & 101.2 & 99.65 & 100.07 & 99.66 & 100.76 \\
\hline $\mathrm{CaO}$ & 0.05 & 0.03 & & 0.16 & 0.12 & $\mathrm{Si}$ & 2.564 & 2.546 & 2.129 & 2.598 & 2.626 & 2.643 & 2.612 \\
\hline $\mathrm{Na}_{2} \mathrm{O}$ & & & & 0.14 & 0.12 & $\mathrm{Al}$ & 1.424 & 1.407 & 1.845 & 1.405 & 1.358 & 1.335 & 1.368 \\
\hline $\mathrm{K}_{2} \mathrm{O}$ & & & & 14.87 & 14.27 & $\mathrm{Ca}$ & 0.470 & 0.441 & 0.923 & 0.396 & 0.366 & 0.372 & 0.392 \\
\hline Total & 99.9 & 99.98 & 101.3 & 97.62 & 98.21 & $\mathrm{Na}$ & 0.527 & 0.585 & 0.099 & 0.585 & 0.632 & 0.646 & 0.625 \\
\hline $\mathrm{Si}$ & 1.002 & 0.999 & 0.001 & 3.012 & 3.011 & $\mathrm{~K}$ & 0.016 & 0.020 & 0.003 & 0.015 & 0.018 & 0.003 & 0.003 \\
\hline $\mathrm{Ti}$ & 0.000 & 0.000 & 0.000 & 0.000 & 0.000 & total & 5.000 & 5.000 & 5.000 & 5.000 & 5.000 & 5.000 & 5.000 \\
\hline $\mathrm{Al}$ & 1.974 & 1.983 & 1.988 & 1.011 & 1.030 & & & & & & & & \\
\hline $\mathrm{Fe}^{3+}$ & 0.022 & 0.018 & 0.000 & 0.000 & 0.000 & & & & & & & & \\
\hline $\mathrm{Fe}^{2+}$ & 0.000 & 0.000 & 0.015 & 0.000 & 0.000 & & & & & & & & \\
\hline $\mathrm{Mn}$ & 0.000 & 0.000 & 0.001 & 0.000 & 0.000 & & & & & & & & \\
\hline $\mathrm{Ca}$ & 0.001 & 0.001 & 0.000 & 0.008 & 0.006 & & & & & & & & \\
\hline $\mathrm{Na}$ & 0.000 & 0.000 & 0.000 & 0.013 & 0.011 & & & & & & & & \\
\hline K & 0.000 & 0.000 & 0.000 & 0.890 & 0.845 & & & & & & & & \\
\hline Total & 3.000 & 3.001 & 2.005 & 4.934 & 4.902 & & & & & & & & \\
\hline
\end{tabular}




\subsection{Reaction textures and evolution}

Textural and compositional relationships suggest a threestage evolution of the sapphirine granulites: (1) a prograde stage which saw the growth of what are now the inclusions of sapphirine, spinel and sillimanite, (2) A peak-metamorphic stage which resulted in the stable assemblage of quartz, garnet, orthopyroxene, sillimanite, sapphirine and spinel and (3) a retrograde stage. We undertook estimates of $P$ and $T$ for each stage using both cations exchange thermometry (garnet-orthopyroxene and sapphirine-spinel) and isochemical sections. The summary of results obtained from geothermobarometry is given in Table 10.

A careful examination of the mineral inclusions in many garnet grains from the $\mathrm{Mg}-\mathrm{Al}$ granulites shows that most of these are monophase inclusions of sapphirine, quartz, spinel or sillimanite. While sapphirine and quartz are occasionally contained within a single garnet grain, they do not show mutual grain contact. This is may be due to the low modal abundance of sapphirine included within garnet. As sapphirine + quartz equilibrium has been found in sample G-09 (Figure 3e), we infer that the sapphirine and quartz inclusions within garnet may also have formed during the peak stage. In all samples examined, sillimanite is the only aluminosilicate present. It occurs as inclusions within garnet in quartzo-feldspathic domains as well as in the matrix. This suggests that the dominant phase of high-grade metamorphism of the studied area took place within the stability field of sillimanite.

Inclusions of spinel and quartz within sapphirine (Figure 2f) are inferred to be stable before sapphirine formation, and may indicate the following reaction:

$$
\mathrm{Spl}+\mathrm{Qtz}+\mathrm{Sil}=\mathrm{Spr}
$$

The presence of biotite, plagioclase and quartz inclusions in garnet (Figure 3b,c,d) suggest progress of a dehydration melting reaction during prograde heating through the stability field of sillimanite:

$$
\mathrm{Bt}+\mathrm{Pl}+\mathrm{Qtz}=\mathrm{Grt} \pm \mathrm{Opx}+\mathrm{L}
$$

where $\mathrm{L}$ is melt phase. There is no preferred orientation for the inclusions, which indicates static conditions during heating.

\begin{tabular}{|c|c|c|c|c|c|c|c|c|}
\hline Sample \# & G-03 & G-05 & G-07 & G-14A & G-14AB & G-06 & G-09 & G-12 \\
\hline \multicolumn{9}{|l|}{ Fe-Mg Grt-Opx } \\
\hline Ln-Kd (Grt-Opx) & 0.821 & 0.668 & 0.783 & 0.605 & 0.588 & 1.061 & 0.954 & 1.039 \\
\hline Kawasaki and Matsui, 1983 & 753 & 847 & 772 & 892 & 903 & 633 & 684 & 644 \\
\hline Aranovich, 1984 & 705 & 802 & 716 & 862 & 875 & 601 & 642 & 607 \\
\hline Sen and Bhattacharya, 1984 & 904 & 1069 & 935 & 1149 & 1171 & 716 & 790 & 733 \\
\hline Harley, 1985 & 807 & 907 & 827 & 954 & 966 & 684 & 738 & 696 \\
\hline Lee and Ganguly, 1988 & 890 & 998 & 909 & 1050 & 1063 & 760 & 818 & 734 \\
\hline Bhattacharya et al., 1991 & 817 & 907 & 832 & 951 & 962 & 705 & 752 & 717 \\
\hline Lavrent'eva and Perchuk, 1990 & 649 & 790 & 672 & 868 & 887 & 534 & 578 & 533 \\
\hline Lal, 1993 & 705 & 810 & 719 & 856 & 889 & 598 & 644 & 607 \\
\hline Harley, 1984a & 842 & 946 & 863 & & & 711 & 767 & 722 \\
\hline \multicolumn{9}{|l|}{ Spr-Spl } \\
\hline Owen and Greenough (1991) & & 865 & 896 & & & $746(884)$ & $765(776)$ & 804 \\
\hline Das et al. (2006) & & 994 & 1018 & & & $875(1014)$ & $894(906)$ & 934 \\
\hline \multicolumn{9}{|l|}{ Grt-Crd } \\
\hline Ln-Kd (Grt-Crd) & & & & & & 2.221 & 2.109 & 1.873 \\
\hline Thompson, 1976 & & & & & & 621 & 654 & 733 \\
\hline Holdaway and Lee, 1977 & & & & & & 609 & 638 & 705 \\
\hline Bhattacharya et al., 1988 & & & & & & 622 & 630 & 696 \\
\hline Perchuk et al., 1985 & & & & & & 613 & 642 & 709 \\
\hline Wells, 1977 & & & & & & 596 & 629 & 705 \\
\hline Dwivedi et al., 1998 & & & & & & 638 & 642 & 708 \\
\hline \multicolumn{9}{|l|}{ Grt-Opx-Pl-Qtz } \\
\hline Perkins and Newton, 1981 & & & & & & & 7.1 & 7.4 \\
\hline Perkins and Chipera, 1985 & & & & & & & 7.9 & 8.3 \\
\hline Eckert et al., 1991 & & & & & & & 7.3 & 7.7 \\
\hline \multicolumn{9}{|l|}{ Grt-Opx } \\
\hline Harley and Green, 1982 & & & & & & & 8.7 & 9.4 \\
\hline Nickel and Green, 1985 & 5.6 & 3.4 & 4.7 & 10.8 & 11.3 & 8.8 & 9.0 & 7.2 \\
\hline Brey and Kohler, 1990 & 8.7 & 5.7 & 7.1 & 12.42 & 12.78 & 11 & 11.3 & 9.6 \\
\hline
\end{tabular}

Table 10. Thermobarometric results of Grt-Opx, Grt-Opx-Pl-Qtz, Spr-Spl and Grt-Crd 
Inclusions of sapphirine, sillimanite and spinel in garnet (Figure 2a,c,d) and the presence of corundum (Figure 2b) in these domains suggest a simplified reaction:

$$
\mathrm{Spr}+\mathrm{Sil}+\mathrm{Spl}=\mathrm{Grt} \pm \mathrm{Crn}
$$

This is consistent with the breakdown of the inclusion assemblage sapphirine + sillimanite + spinel to the matrix assemblage garnet + corundum.

The sapphirine inclusion-bearing samples contains a stable assemblage of sapphirine + quartz assemblage, suggesting that the two minerals assumed to be in equilibrium formed in the stability field of sapphirine and quartz $\left(T \sim 1000^{\circ} \mathrm{C}\right)$ probably by a reaction such as

$$
\mathrm{Spl}+\mathrm{Qtz}=\mathrm{Spr}
$$

The analysed sapphirine is a 7:9:3 end member on the basis of $(\mathrm{Mg}, \mathrm{Fe}) \mathrm{O}: \mathrm{Al}_{2} \mathrm{O}_{3}: \mathrm{SiO}_{2}$ ratio. As sapphirine chemistry is close to the 7:9:3 end member or even more aluminous, sillimanite is required as a reactant phase to form sapphirine [7:9:3], although sapphirine [2:2:1] can be formed directly from spinel + quartz (Bhattacharya and Kar, 2002). As sillimanite was also observed in the inclusions, we infer that reaction (1) took place within the stability field of sapphirine + quartz. Coarse-grained orthopyroxene and sillimanite occur together in the matrix along with small quartz grains suggesting that orthopyroxene + sillimanite + quartz was a stable assemblage. According to the FMAS petrogenetic grid of Harley (1998b), the $P-$ $T$ condition of this assemblage corresponds to $P>10 \mathrm{kbars}$ and $T \sim 1030^{\circ} \mathrm{C}$. The orthopyroxene + sillimanite + quartz assemblage likely formed at the peak-UHT stage.

Retrograde textures observed as intergrowths of cordierite between orthopyroxene and sillimanite and biotite coronas around early coarse-grained minerals, such as garnet, reflect decreasing $P-T$ conditions. One example is the occurrence of cordierite 'moats' separating orthopyroxene and sillimanite in the presence of quartz, suggesting the progress of the following FMAS continuous reaction:

$$
\mathrm{Opx}+\mathrm{Sil}+\mathrm{Qtz}=\mathrm{Crd}
$$

This cordierite producing reaction is characterized by decompression.

In melanocratic domains, coarse spinel included within the garnet surrounded by a broad rim of sillimanite suggests a reaction such as

$$
\mathrm{Spl}+\mathrm{Qtz}=\mathrm{Grt}+\mathrm{Sil}
$$

Retrograde biotite replacing inclusion-free garnet suggests the progress of the following retrograde reaction:

$$
\mathrm{Opx}+\mathrm{Kfs}+\mathrm{H}_{2} \mathrm{O}=\mathrm{Bt}+\mathrm{Qtz}
$$

\subsection{Metamorphic pressure-temperature conditions}

The high $\mathrm{Al}$ content of peak-metamorphic orthopyroxene ( $>10$ wt $\% \mathrm{Al}_{2} \mathrm{O}_{3}$ ) indicates UHT conditions with temperatures $>900^{\circ} \mathrm{C}$ (Harley, 1998b). UHT conditions are furthermore supported by the prograde biotite-dehydration reaction (2) and the rare preservation of prograde sapphirine + quartz which point to peak temperatures between 890 and $990^{\circ} \mathrm{C}$ at relatively low pressure. The retrograde evolution is dominated by decompression to $P<8$ kbars as indicated by the formation of cordierite-orthopyroxene symplectites and biotite replacing the peak-metamorphic garnet.

The assemblages and microstructures observed in the studied rocks allow us to apply several conventional geothermobarometers to infer the peak and retrograde metamorphic conditions. We briefly summarize below the computed $P-T$ conditions from geothermobarometers that are appropriate for the assemblages in the studied samples. Thermobarometric calculations were accomplished using the GPT software (Reche and Martinez, 1996).

\subsubsection{Garnet-orthopyroxene geothermometer}

This thermometer was applied to orthopyroxene in equilibrium with garnet. Peak-metamorphic conditions were calculated (Table 10) using the core compositions of coexisting aluminous orthopyroxene, garnet and plagioclase. Garnet-orthopyroxene $\mathrm{Fe}-\mathrm{Mg}$ exchange geothermometry (Lee and Ganguly, 1988; Bhattacharya et al., 1991) yields UHTs between 930 and $1171^{\circ} \mathrm{C}$ at a reference pressure of $9.5 \mathrm{kbars}$. The ultrahigh garnet-orthopyroxene $\mathrm{Fe}-\mathrm{Mg}$ temperatures are supported by the results of garnetorthopyroxene geothermometry of Harley (1998b), which yields temperatures up to $992^{\circ} \mathrm{C}$.

\subsubsection{Sapphirine-spinel geothermometer}

A thermometer based on $\mathrm{Fe}^{2+}-\mathrm{Mg}$ distribution between coexisting sapphirine and spinel, preserved as inclusions within garnet, provides a temperature estimate for minerals formed on the prograde path. As shown in Figure 2e, sapphirine and spinel coexist with no reaction texture displayed between them, although both are included within garnet. We, therefore, regard the two minerals to be in equilibrium, and apply the sapphirine-spinel geothermometer to the mineral pairs (Owen and Greenough, 1991). This method is based on empirical determination of entropy and enthalpy of the reaction. In addition, we applied a more recent sapphirinespinel geothermometer (Das et al., 2003), which was formulated using their experimental data at $9-12 \mathrm{kbars}$ and $850-1100^{\circ} \mathrm{C}$. Direct application of these two published calibrations yields temperatures ranging from 746 to $1018^{\circ} \mathrm{C}$ (Table 10).

Temperatures of around $750^{\circ} \mathrm{C}$ have been calculated for the sapphirine intergrowths and cordierite 'moats' 
separating orthopyroxene and sillimanite using various GrtCrd geothermobarometers and the mineral compositions of coexisting phases in samples G-6, G-09 and G-12.

\subsubsection{Al solubility in orthopyroxene}

The Al content of orthopyroxene in association with sapphirine and quartz has now been used as a reliable sensor for UHT metamorphism (Harley and Motoyoshi, 2000; Hollis and Harley, 2003; Harley, 2004) Al zoning in orthopyroxene has been experimentally calibrated in MAS system (Anastasiou and Seifert, 1972; Arima and Onuma, 1977; Hollis and Harley, 2003) as well as theoretically modelled in the more complex FMAS system (Hensen and Harley, 1990). Harley and Motoyoshi (2000) estimated temperatures in excess of $1100^{\circ} \mathrm{C}$ in the Napier Complex, where orthopyroxene contains $12.5 \mathrm{wt} \% \mathrm{Al}_{2} \mathrm{O}_{3}$, using this assemblage. This technique is able to retrieve extremely high temperatures, hitherto unrecorded by exchange thermometers.

Orthopyroxene in this study contains $>10 \mathrm{wt} \% \mathrm{Al}_{2} \mathrm{O}_{3}$ in the core and gives temperature of $1000^{\circ} \mathrm{C}$ when plotted in the sapphirine + quartz + orthopyroxene field of the Al-isopleth diagram of Harley (2004). This assemblage has a distinct stability field towards high temperature in the FMAS petrogenetic grid. The temperature of the [Grt] invariant point in this grid is not experimentally constrained, but must be around $950^{\circ} \mathrm{C}$ at $9 \mathrm{kbars}$, as evident from theoretical and natural data (Dasgupta et al., 1995). However, in KFMASH system, an equivalent invariant point [Grt, Bt, Kfs] has been experimentally constrained at similar temperature at slightly lower pressure $\left(1000^{\circ} \mathrm{C}\right.$ at $7.5 \mathrm{kbars}$; Das et al., 2003). The peak assemblage of sapphirine + orthopyroxene + quartz is, therefore, stabilized at $T>950^{\circ} \mathrm{C}$. The Al content of orthopyroxene in the sapphirine granulites (G-06) is much lower $(8.1 \mathrm{wt} \%$ $\mathrm{Al}_{2} \mathrm{O}_{3}$ ), suggesting at least a $70-80^{\circ} \mathrm{C}$ drop in temperature from the peak according to the recent experimental data (Hollis and Harley, 2003). Experimental data in KFMASH system, however, suggest that sapphirine + quartz bearing assemblages can stabilize at lower pressure of $\sim 8$ kbars (Das et al., 2003). This is in agreement with the barometric data of $8.4 \mathrm{kbars}$ calculated by earlier workers from a variety of $P-T$ sensors in similar rocks in this area (Mohan et al., 1997).

\subsubsection{Garnet-orthopyroxene geobarometers}

Corresponding pressures were calculated with the garnetorthopyroxene geobarometer using the calibrations of Harley and Green (1982), Nickel and Green (1985) and Brey and Kohler (1990) and results are given in Table 10. Calculated pressures range from 3.4 to $12.78 \mathrm{kbars}$. Pressures were also calculated by the garnet-orthopyroxene-plagioclase-quartz geobarometer using the calibrations of Perkins and Newton (1981), Perkins and Chipera (1985) and Eckert et al. (1991) for the $\mathrm{Mg}$-end member reaction.

\subsection{Petrogenetic grid and isochemical section modelling}

The first evidence for the $P-T$ conditions attained during the metamorphic evolution of the sapphirine granulites is given by the observed mineral assemblages, reaction textures and mineral compositions. The high $\mathrm{Al}$ content of peakmetamorphic orthopyroxene $\left(>10 \mathrm{wt} \% \quad \mathrm{Al}_{2} \mathrm{O}_{3}\right)$ indicates UHT condition with temperatures $>900^{\circ} \mathrm{C}$ (Harley, 1998a). UHT conditions are furthermore supported by the prograde biotite-dehydration reaction (2) and the rare preservation of prograde sapphirine + quartz which point to peak temperatures between 890 and $990^{\circ} \mathrm{C}$ at relatively low pressures. The early stage mineral reactions observed in the sapphirinebearing granulites can be analysed in the model FMAS and KFMAS system (Figure 6) as given in Harley (1998b) with experimental calibrations (Bertrand et al., 1991). The sapphirine forming reaction possibly took place at rising temperatures under lower pressures conditions preceding garnet forming reactions. The sapphirine breakdown and garnet forming reactions preceded with increasing pressure under high temperature $\sim 950^{\circ} \mathrm{C} \pm 30$.

A series of $P-T$ isochemical sections relevant to the mineral assemblages preserved in these rocks are presented in Figure 6. The input bulk rock composition of the sapphirine granulite samples (G-05, G-06) resulted from the projection of the actual rock composition (Table 7) into the NCKFMASHTO system. The resulting isochemical sections (Figure 7a,b) indicates that the preserved peak assemblage biotite-sapphirine-orthopyroxene is stable in a $P-T$ field with a range of temperatures up to $1050^{\circ} \mathrm{C}$ and at pressures $>7.6 \mathrm{kbars}$ (Figure $7 \mathrm{a}$ ) and $>6.0 \mathrm{kbars}$ (Figure 7b). These isochemical sections also show the melt to be stable with the peak assemblage. The generally migmatitic character of these samples indicate that they were once melt-bearing, though microstructures indicative of former presence of melt have not been observed in these samples.

The peak assemblage for the sample G-14 is inferred to contain garnet-orthopyroxene-K-feldspar-plagioclaserutile-quartz. The $P-T$ field in the computed isochemical section (Figure 7c) defines peak-metamorphic conditions for the sample at a range of $T$ up to $\sim 980^{\circ} \mathrm{C}$ at $P$ up to $8.8 \mathrm{kbars}$. The preserved peak assemblage of sample G-09, orthopyroxene-sillimanite-quartz-plagioclase-rutile-quartz is stable at $1080^{\circ} \mathrm{C}$ and at pressures $>9.0$ (Figure $7 \mathrm{~d}$ ).

\subsection{P-T history and $P-T$ path}

Textural, compositional and $P-T$ estimates for these samples suggest a three-stage evolution of the sapphirine granulites and associated garnet-orthopyroxene granulites: (1) A prograde path $\left(\mathrm{M}_{1}\right)$ which produced the assemblages 


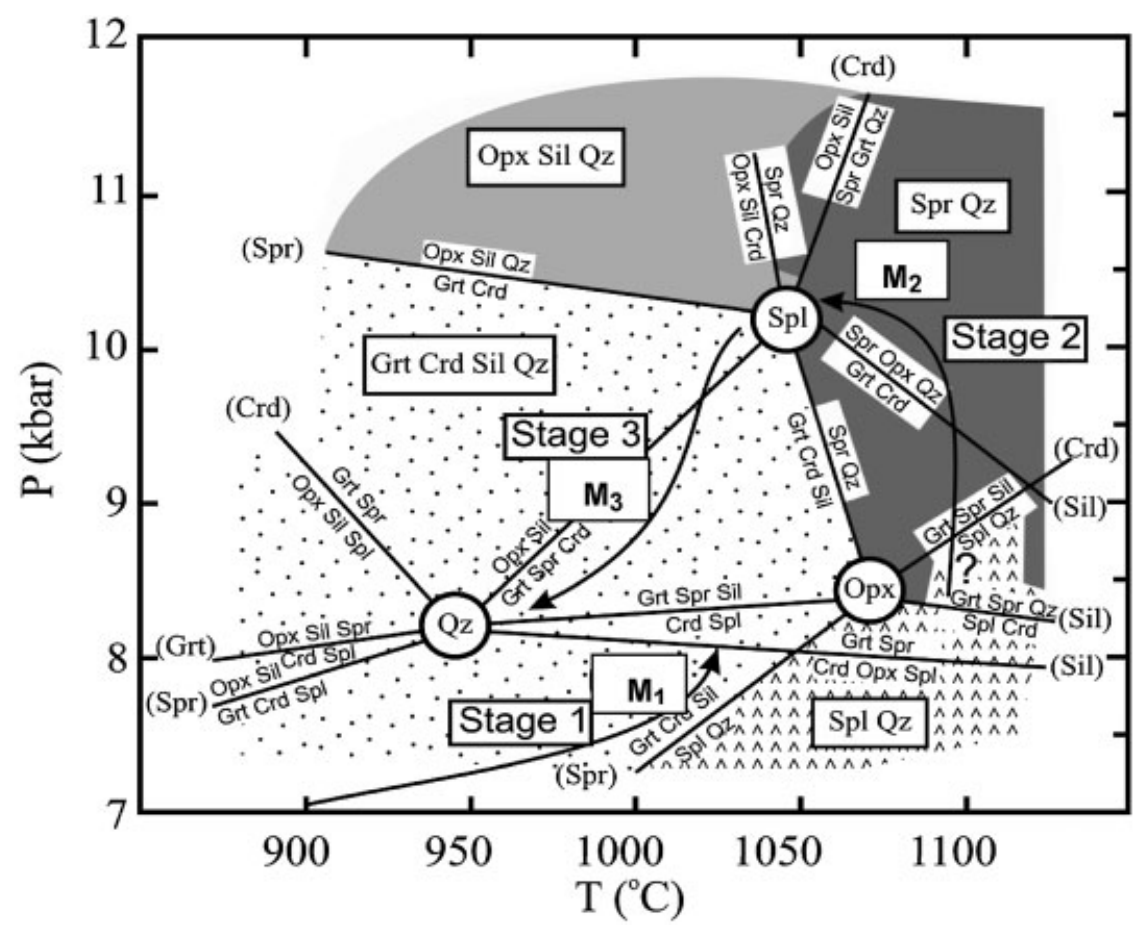

Figure 6. Petrogenetic grid for FMAS and KFMAS systems (Hensen and Harley, 1990; Bertrand et al., 1991; Harley, 1998a) showing univariant reactions and divariant fields relevant to the interpretation of the possible $P-T$ reaction inferred from the textures. Inferred $P-T$ trajectories followed by G. Madugula UHT granulites as deduced from the observed sequence of metamorphic reactions from $\mathrm{M}_{1}$ to $\mathrm{M}_{3}$ are also shown.

preserved as inclusions (sapphirine, biotite and quartz); (2) Peak, UHT, metamorphism $\left(\mathrm{M}_{2}\right)$ with an assemblage of porphyroblastic garnet-orthopyroxene-sillimanite-spinel and (3) a retrogression $\left(\mathrm{M}_{3}\right)$ that resulted in orthopyroxene-cordierite symplectites and biotite rims on garnet.

\subsection{1. $M_{1}$ : prograde path}

The unique prograde inclusion assemblages and other equilibrium assemblages in the sapphirine granulites and garnet-orthopyroxene granulites of this study allow us to construct the $P-T$ history of the rock. Thermometry results of sapphirine and spinel inclusions indicate conditions of prograde metamorphism at $9-12 \mathrm{kbars}$ and $850-1100^{\circ} \mathrm{C}$. Peak metamorphic conditions of $950^{\circ} \mathrm{C}$ have been estimated using Opx isopleths and isochemical sections which are consistent with the stability of sapphirine and spinel inclusions. Experimental data in the KFMASH system, however, suggest that sapphirine + quartz bearing assemblages can stabilize at lower pressure of $\sim 8$ kbars (Das et al., 2003). This is in agreement with the barometric data of 8.4 kbars calculated by earlier workers from a variety of $P-T$ sensors in similar rocks in this area (Mohan et al., 1997).

\subsection{2. $M_{2}$ : peak metamorphic conditions}

The growth of porphyroblasts orthopyroxene-sillimanitequartz assemblage in sample G-14A is indicative of a high $P$ metamorphic event. As the invariant point of $[\mathrm{Spl}]$ in the
FMAS system corresponds to the $P-T$ conditions of $1050^{\circ} \mathrm{C}$ at $10 \mathrm{kbars}$ (Harley, 1998b), we infer that this stage took place at pressures higher than $>9$ kbars. The calculated pressures with the garnet-orthopyroxene geobarometer for these samples range from 10.8 to 12.78 kbars.

\subsection{3. $M_{3}$ : retrograde path}

The sapphirine-bearing granulites discussed exhibit various retrograde textures as indicated by reactions (5)-(7) formed during the decompression stage $\left(\mathrm{M}_{3}\right)$. Among the textures observed in the studied samples, one of the most spectacular reaction textures is the cordierite 'moats' separating sillimanite and orthopyroxene (Figure 5c). This is one of the most common decompression reaction textures documented from various granulite terrains in other parts of the world and the texture is diagnostic of near ITD after peak metamorphism (Harley, 1989; Santosh et al., 2007). The $P-$ $T$ conditions for the sapphirine intergrowths and cordierite moats, estimated by geothermobarometry and the mineral compositions of coexisting phases in samples G-6 and G-12 are around $750^{\circ} \mathrm{C}$ which is lower than the early stage UHT conditions in $\mathrm{M}_{1}$. Corresponding pressures were calculated using a geobarometry range from 7.1 to 11 . The relative $P-T$ path is broadly anticlockwise (Figure 8), sapphirine formation and breakdown are compatible with pressure increase between $\mathrm{M}_{1}$ and $\mathrm{M}_{2}$ and decompression during $\mathrm{M}_{3}$. 

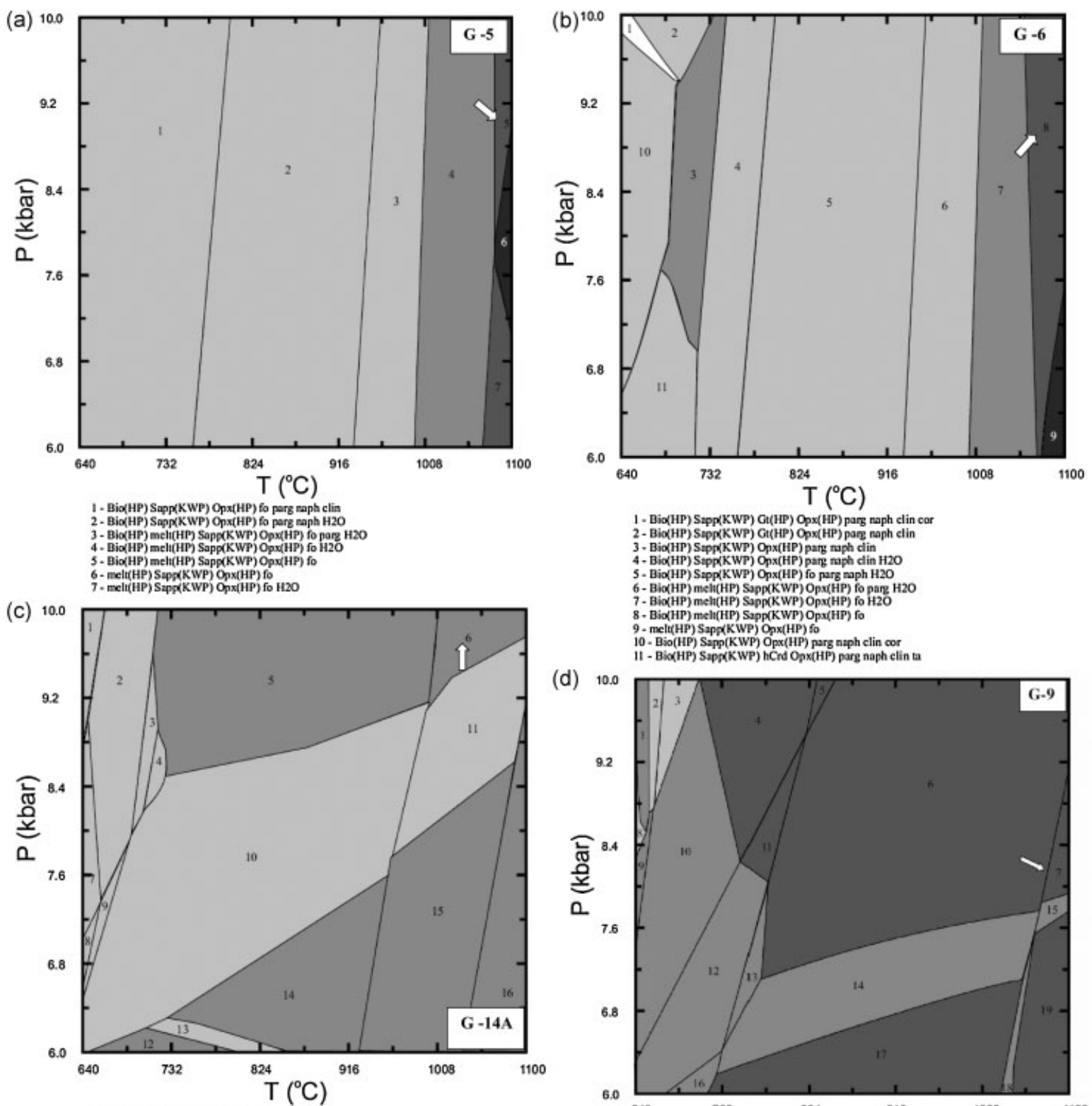

1. Bio(HP) Sapp(KWP) Gt(HP) Opx(HP) parg naph clin cor

2- Bio(HP) SappXKWP) Gt(HP) Opx(HP) page raph el

3. Bio(HP) Sapp(KWP) Opx(HP) parg maph din

4. Bio HP) Sapp(KWP) Opx(HP) parg maph din H2O

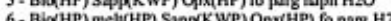

7. $\mathrm{Bi \alpha}(\mathrm{HP})$ mel(t)

8. Bio(HP) meli(HP) Supp(KWPPOP (HP) fo

9. melt(HP) Sapp(KWP) Opx(HP) fo

10 - Bio(HP) Sapp(KWP) Opx(HP) parg naph clin co

II - Bic(HP) Sapp(KWP) hCrd Opx(HP) parg naph elin ta

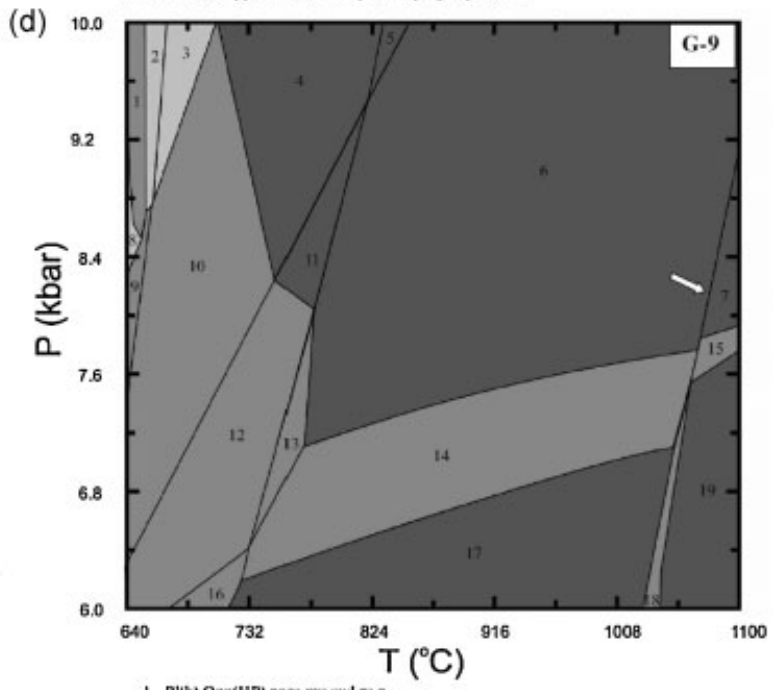

1- Bic(HP) Gi(HP) pa sud ta ru q

- Bio(HP) Pl(h) Gi(HP) Opx(HP) sod rua

4 - Bico(HP) PI(h) Gi(HP) Opx(HP) ky rug

5 - Bio(HP) PI(h) Gi(HP) Opx(HP) ru

6- $P($ (h) Gu(HP) Opx(HP) san ru q

7io(HP) PI(h) GI(HP) clin sud nu q

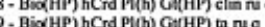

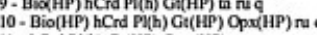

11 - $\mathrm{hCrd} P(\mathrm{~h}(\mathrm{~h}) \mathrm{Gt}(\mathrm{HP}) \mathrm{Opx}$ (HP) san ru $\mathrm{q}$

12 - Bio(HP) hCrd P(h) Opx(HP) ilm q

13- Bio(HP) hCrd Pl(h) Opx(HP) ru ilm

14 - Bio(HP) hCrd Py(h) Opx(HP) ni

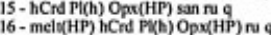

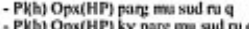

- Pl(t) Opx(HF) ky parg mu sud nu q

4. PH, OpxiHP) ky men

5. Phb) Opx(HP) ky san ne

6- Phb) Opx(HP) sill san ru q

7. meth(IIP) PI(t) Opx(HP) sall ru q

8- PV(b) Opx(HP) parg wu phl sud

9 - Ph(h) Opx(HP) mu phl sud na

II. P(h) Opx(HP) sill mu ru q

12. PY(b) Opx(HP) sill mu phl ru g

13. Phit) Oox(HP) sill phl san nu q

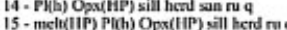

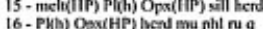

17. Pl(b) Opsitip) berd sin ru q

18 - mett(HP) P(th) Opx(HP) herd san ru a

19- melh(HP) P(th) Opx(IIP) herd nug

Figure 7. $P-T$ isochemical section for bulk composition of sapphirine granulite samples (NCKFMASHTO model system). Univariant fields shown by heavy solid lines, divariant fields by white fill, and higher variance fields by progressively darker shading; in all isochemical sections the lowest variance fields are trivariant. (a) Sample G-05 showing the stability of the preserved peak assemblage biotite-sapphirine-orthopyroxene in a UHT $P-T$ field around $1050^{\circ} \mathrm{C}$ and at pressures $\sim 6-7.6$ kbars. (b) Sample G-06 showing the stability of the preserved peak assemblage biotite-sapphirine-orthopyroxene at temperatures above $\sim 1050^{\circ} \mathrm{C}$. (c) Sample G-14A showing the stability of the preserved peak assemblage of garnet-orthopyroxene-K-feldspar-rutile-quartz at $T=\sim 980^{\circ} \mathrm{C}$ at $P$ at 8.8 kbars. (d) Sample G-09 showing the stability of the preserved peak assemblage of orthopyroxene-sillimanite-quartz-plagioclase-rutile-quartz at $1080^{\circ} \mathrm{C}$ and at pressures $>9.0$ kbars. 


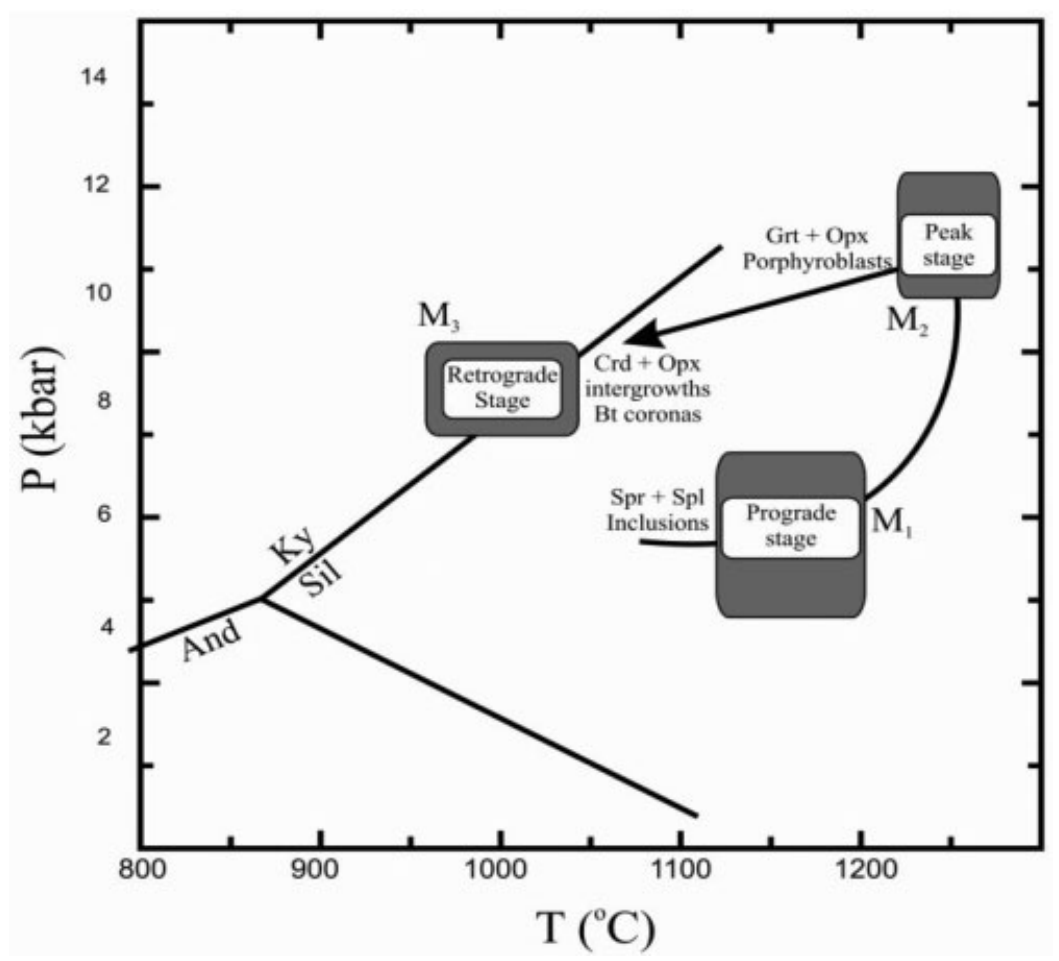

Figure 8. The anticlockwise $P-T$ path (grey arrow) indicates a three-stage evolution: $\mathrm{M}_{1}$ inclusion assemblages with sapphirine, spinel and quartz on the prograde path. $\mathrm{M}_{2}$ peak UHT metamorphism with an assemblage of porphyroblastic Grt-Opx. $\mathrm{M}_{3}$ retrograde path resulting in Opx-Crd symplectites and Bt rims on Grt.

\section{DISCUSSION AND CONCLUSIONS}

The stable coexistence of sapphirine and quartz and the occurrence of the assemblage of high alumina orthopyroxene + sillimanite + garnet + quartz in the samples of this study provide robust evidence for the extreme crustal metamorphism of this region. Low pressure prograde heating proceeded through the sillimanite stability field and resulted in the stabilization of UHT coarse-grained garnet and orthopyroxene porphyroblasts through dehydration melting reactions. As a result of preservation of highest grade mineral compositions in the garnet and orthopyroxene porphyroblasts, the conventional thermobarometery complimented by the isochemical section approach yields UHT conditions $\left(>959^{\circ} \mathrm{C},>10 \mathrm{kbars}\right.$ for the formation of peak metamorphic $\left(\mathrm{M}_{2}\right)$ assemblages.

An early UHT $\left(\sim 1000^{\circ} \mathrm{C}\right)$ metamorphic event $\left(\mathrm{M}_{1}\right)$ at crustal depths of $30-35 \mathrm{~km}(810 \mathrm{kbars})$ is reported from high $\mathrm{Mg}-\mathrm{Al}$ granulites in several areas north of Godavari Rift, including Anantagiri (Sengupta et al., 1990), Anakapalle (Dasgupta et al., 1994; Sanyal and Fukuoka, 1995; Rickers et al., 2001b), Araku (Sengupta et al., 1991), Paderu (Lal et al., 1987; Pal and Bose, 1997; Bhattacharya and Kar, 2002), Rayagada (Shaw and Arima, 1996), Sunkarametta (Bose et al., 2000) and Rajamundry (Dasgupta, 1995). Due to the high reaction rates which take place under UHT conditions, the early metamorphic textures are in most areas in this region nearly completely obliterated and hence the prograde path of metamorphism can seldom be deduced. However, it was possible to reconstruct the prograde path of this $M_{1}$ metamorphism for a few areas. Dasgupta and Sengupta (2003 and references therein) argued for an anticlockwise trajectory for the prograde $\mathrm{M}_{1}$ event in which the UHT metamorphic peak is followed by near IBC. Lal et al. (1987) had earlier suggested a clockwise path with decompression following the UHT peak condition for the rocks in the Paderu area. However, Pal and Bose (1997) and Sengupta et al. (1997) reinterpreted the petrographic data of Lal et al. (1987) to make them consistent with a general anticlockwise path, stating that the prograde path reached peak values of $P=9.5 \mathrm{kbars}, T=\sim 1000^{\circ} \mathrm{C}$, followed by near IBC to $P=9 \mathrm{kbars}, T=900^{\circ} \mathrm{C}$. At Paderu, Bhattacharya and Kar (2002) and Bhattacharya et al. (2003) also proposed a clockwise path, in which peak $P-T$ conditions of $\sim 10$ kbars and $\sim 1000^{\circ} \mathrm{C}$ was followed by high temperature decompression and subsequent IBC.

The area of G. Madugula has been previously interpreted (Mohan et al., 1997) to have attained peak conditions of $8.4 \mathrm{kbars}, \sim 900^{\circ} \mathrm{C}$, followed by substantial decompression (by up to $3 \mathrm{kbars}$ ) and moderate cooling (of $150^{\circ}-200^{\circ} \mathrm{C}$ ). However, we have in this study provided textural and compositional evidence in favour of an anticlockwise $P-T$ 
trajectory comprising an early low pressure-high temperature prograde culminating at UHT conditions of 8-10 kbars and $>950^{\circ} \mathrm{C}$. Bhattacharya and Gupta (2001) suggested that the differences in the peak $P-T$ paths in different areas of this region may indicate the existence of spatially disparate metamorphic sectors within the granulite belt. The proposition that in the region north of the Godavari Rift an UHT event predates a lower temperature granulite facies event is contradicted by Bhattacharya and Gupta (2001). They favour a model of a single granulite facies metamorphic event. However, the large database generated by Simmat and Raith (2008) on chemical dating of monazites in samples collected throughout the EGB indicates a complex polycyclic evolution of the EGB. Older electron microprobe spot ages of monazite are obtained from small grains armoured in porphyroblastic garnets or in the interiors of such grains and also in the cores of the grains in the matrix. The host garnet porphyroblasts also contain inclusions of sillimanite, spinel and rutile at several places and therefore these old dates are considered to represent the prograde stage of the early UHT metamorphism.

Thus, conflicting interpretations of the $P-T$ paths and single or polymetamorphic evolution of the high $\mathrm{Mg}-\mathrm{Al}$ granulites have resulted in controversy regarding the evolution of the granulite facies EGB. Calculated isochemical sections may provide new insight into this controversy, aided by constraints from geochronology and mineral textural relationships. An isochemical section approach, considering individual texture bulk composition, has yielded more robust constraints than only using semiquantitative $P-T$ grids and conventional thermobarometry. Establishing the exact temporal relationship of the high $\mathrm{Mg}-\mathrm{Al}$ granulites in various localities is largely a geochronological problem. However, isochemical sections may be used to support a shared history, consistent with the preservation of composite inclusions and geochronology. A detailed petrographic and mineralogical study of multiphase prograde inclusions within garnet from sapphirine granulites has yielded valuable information on extreme crustal metamorphism at UHT conditions in the present study area in the continental deep crust of EGB. This study demonstrates the use of inclusion petrography and isochemical sections from bulk compositions in understanding high-grade metamorphic processes and provides evidence in favour of an anticlockwise $P-T$ trajectory. If the derived $P-T$ path is indeed representative of the conditions of metamorphism in this region, existing models for the evolution of EGB may require revision, as the mechanism of formation and styles of exhumation of UHT rocks have important implications on geodynamic models (e.g. Santosh et al., 2009b; Santosh and Kusky, 2010). Furthermore, it may be possible to use calculated isochemical sections in conjunction with independent information to resolve apparently different $P-T$ evolution of rocks of markedly different composition.

\section{ACKNOWLEDGEMENTS}

The authors thank Prof. M. Santosh for the invitation to submit the paper. They also thank Sri C. S. Gundewar (Divisional Head, Ore Dressing Division), Indian Bureau of Mines, Nagpur, for according permission to carry out EPMA studies on our samples. CVDR thanks Drs Dave Kelsey and Caroline Forbes and an anonymous referee for their valuable comments and suggestions for improvement on the earlier draft of the manuscript.

\section{REFERENCES}

Anastasiou, P., Seifert, F. 1972. Solid solubility of $\mathrm{Al}_{2} \mathrm{O}_{3}$ in enstatite at high temperatures and $1-5 \mathrm{~kb}$ water pressure. Contributions to Mineralogy and Petrology 34, 272-287.

Aranovich, L.Y. 1984. Biotite-garnet equilibria in metapelites: II. Calculation of T, P and water fugacity. Contributions to Physico-Chemical Petrology 12, 92-103. (in Russian).

Arima, M., Onuma, K. 1977. The solubility of alumina in enstatite and the phase equilibria in the join $\mathrm{MgSiO}_{3}-\mathrm{MgAl}_{2} \mathrm{SiO}_{6}$ at $10-25 \mathrm{kbar}$. Contributions to Mineralogy and Petrology 61, 251-265.

Armbruster, T., Bloss, F.D. 1980. Channel $\mathrm{CO}_{2}$ in cordierites. Nature 286, 140-141.

Asami, M., Grew, E.S., Makimoto, H. 2007. Relict sapphirine + kyanite and spinel + kyanite associations in pyropic garnet from the eastern Sør Rondane Mountains, East Antarctica. Lithos 93, 107-125.

Bertrand, P., Ellis, D.J., Green, D.H. 1991. The stability of sapphirinequartz and hypersthene-sillimanite-quartz assemblages: an experimental investigation in the system $\mathrm{FeO}-\mathrm{MgO}-\mathrm{Al}_{2} \mathrm{O}_{3}-\mathrm{SiO}_{2}$ under $\mathrm{H}_{2} \mathrm{O}$ and $\mathrm{CO}_{2}$ conditions. Contributions to Mineralogy and Petrology 108, 55-71.

Bhattacharya, S. 1996. Eastern Ghats granulite terrain of India: an overview. Journal of Southeast Asian Earth Sciences 14, 165-174.

Bhattacharya, S. 1997. Evolution of Eastern Ghats granulite belt of India in a compressional tectonic regime and juxtaposition against iron ore craton of Singhbhum by oblique collision-transpression. Proceedings of the Indian Academy of Sciences, Earth and Planetary Sciences 106, 65-75.

Bhattacharya, A., Gupta, S. 2001. A reappraisal of polymetamorphism in the Eastern Ghats belt-A view from North of the Godavari rift. Proceedings of the Indian Academy of Sciences, Earth and Planetary Sciences 110, 369-383.

Bhattacharya, S., Kar, R. 2002. High-temperature dehydration melting and decompressive P-T path in a granulite complex from the Eastern Ghats, India. Contributions to Mineralogy and Petrology 143, 175-191.

Bhattacharya, A., Mazumdar, A.C., Sen, S.K. 1988. Fe-Mg mixing in cordierite: constraints from natural data and implication for cordieritegarnet geotherometery to granulite. American Mineralogist 73, 338-344.

Bhattacharya, S., Kar, R., Misra, S., Teixeira, W. 2001. Early Archaean continental crust in the Eastern Ghats granulite belt, India: isotopic evidence from a charnockite suite. Geological Magazine 138, 609-618.

Bhattacharya, S., Kar, R., Teixeira, W., Basei, M. 2003. High-temperature crustal anatexis in a clockwise P-T-t path: isotopic evidence from a granulite-granitoid suite in the Eastern Ghats belt, India. Journal of the Geological Society 160, 39-46.

Bhattacharya, A., Krishnakumar, K.R., Raith, M., Sen, S.K. 1991. An improved set of a-X parameters for Fe-Mg-Ca garnets and refinements of the orthopyroxene-garnet thermometer and the orthopyroxene-garnetplagioclase-quartz barometer. Journal of Petrology 32, 629-656. 
Bose, S., Das, K. 2007. Sapphirine + quartz assemblage in contrasting textural modes from the Eastern Ghats Belt, India: implications for stability relations in UHT metamorphism and retrograde processes. Gondwana Research 11, 492-503.

Bose, S., Fukuoka, M., Sengupta, P., Dasgupta, S. 2000. Evolution of high-Mg-Al granulites from Sunkarametta, Eastern Ghats, India: evidence for a lower crustal heating-cooling trajectory. Journal of Metamorphic Geology 18, 223-240.

Brandt, S., Klemd, R., Okrusch, M. 2003. Ultrahigh-temperature metamorphism and multistage evolution of garnet-orthopyroxene granulites from the Proterozoic Epupa Complex, NW Namibia. Journal of Petrology 44, 1121-1144.

Brey, G.P., Kohler, T. 1990. Geothermobarometry in four-phase lherzolites II. New thermobarometers, and practical assessment of existing thermobarometers. Journal of Petrology 31, 1353-1378.

Chetty, T.R.K. 2010. Structural architecture of the northern composite terrane, the Eastern Ghats Mobile Belt, India: implications for Gondwana tectonics. Gondwana Research (in press). DOI:10.1016/j.gr.2010.02.006

Connolly, J.A.D. 2005. Computation of phase equilibria by linear programming: a tool for geodynamic modeling and its application to subduction zone decarbonation. Earth and Planetary Science Letters 236, 524-541.

Dallwitz, W.B. 1968. Co-existing sapphirine and quartz in granulite from Enderby Land, Antarctica. Nature 219, 476-477.

Das, S., Bhattacharya, A., Raith, M.M., Bhadra, S., Banerjee, M. 2006. Aluminous sapphirine granulites from the Eastern Ghats Belt (India): phase relations and relevance to counterclockwise P-T history. European Journal of Mineralogy 18, 35-48.

Das, K., Dasgupta, S., Miura, H. 2003. An experimentally constrained petrogenetic grid in the silica-saturated portion of the system KFMASH at high temperatures and pressures. Journal of Petrology 44, 1055-1075.

Dasgupta, S. 1993. Contrasting mineral parageneses in high-temperature calc-silicate granulites: examples from the Eastern Ghats, India. Journal of Metamorphic Geology 11, 193-202.

Dasgupta, S. 1995. Pressure-temperature evolutionary history of the Eastern Ghats granulite province: recent advances and some thoughts. Memoirs-Geological Society of India 34, 101-110.

Dasgupta, S., Sanyal, S., Sengupta, P., Fukuoka, M. 1994. Petrology of granulites from Anakapalle-evidence for Proterozoic decompression in the Eastern Ghats, India. Journal of Petrology 35, 433-459.

Dasgupta, S., Sengupta, P., 2003. Indo-Antarctic correlation; a perspective from the Eastern Ghats granulite belt, India. In: Proterozoic East Gondwana; supercontinent assembly and breakup, Yoshida, M., Windley, B.F., Dasgupta, S. (eds). Geological Society, London, Special Publications, 206: 131-143.

Dasgupta, S., Sengupta, P., Ehl, J., Raith, M., Bardhan, S. 1995. Reaction textures in a suite of spinel granulites from the Eastern Ghats Belt, India: evidence for polymetamorphism, a partial petrogenetic grid in the system KFMASH and the roles of $\mathrm{ZnO}$ and $\mathrm{Fe}_{2} \mathrm{O}_{3}$. Journal of Petrology 36, 435461.

Dasgupta, S., Sengupta, P., Fukuoka, M., Bhattacharya, P.K. 1991. Mafic granulites from the Eastern Ghats, India: further evidence for extremely high temperature crustal metamorphism. Journal of Geology 99, 124-133.

Dwivedi, S.B., Mohan, A., Lal, R.K. 1998. Recalibration of the Fe-Mg exchange reaction between garnet and cordierite as a thermometer. European Journal of Mineralogy 10, 281-289.

Eckert, J.O., Newton, R.C., Kleppa, O.J. 1991. The $\Delta \mathrm{H}$ of reaction and recalibration of garnet-pyroxene- plagioclase-quartz geobarometers in the CMAS system by solution calorimetry. American Mineralogist 76, $148-160$.

Ellis, D.J., Sheraton, J.W., England, R.N., Dallwitz, W.B. 1980. Osumilite-sapphirine-quartz granulites from Enderby Land Antarcticamineral assemblages and reactions. Contributions to Mineralogy and Petrology 72, 123-143.

Fitzsimons, I.C.W., Harley, S.L. 1994. The influence of retrograde cation exchange on granulite P-T estimates and a convergence technique for the recovery of peak metamorphic conditions. Journal of Petrology 35, 543576.
Frost, B.R., Chacko, T. 1989. The granulite uncertainty principle: limitations on thermobarometry in granulites. Journal of Geology 97, 435450.

Grew, E.S. 1980. Sapphirine + Quartz association from Archean rocks in Enderby Land, Antarctica. American Mineralogist 65, 821-836.

Gupta, S. 2004. The Eastern Ghats Belt, India; a new look at an old orogen. Special Publication Series-Geological Survey of India 84, 75-100.

Harley, S.L. 1984a. An experimental study of the partitioning of the Fe and $\mathrm{Mg}$ between garnet and orthopyroxene. Contributions to Mineralogy and Petrology 86, 359-373.

Harley, S.L. 1985. Garnet-orthopyroxene-bearing granulites from Enderby Land, Antarctica: metamorphic pressure-temperature-time evolution of the Archaean Napier Complex. Journal of Petrology 26, 819-856.

Harley, S.L. 1989. The origins of granulites: a metamorphic perspective. Geological Magazine 126, 215-247.

Harley, S.L. 1998a. An appraisal of peak temperatures and thermal histories in ultrahigh-temperature (UHT) crustal metamorphism; the significance of aluminous orthopyroxene. In: International symposium on Origin and evolution of continents, Motoyoshi, Y., Shiraishi, K. (eds). 53: Memoirs of National Institute of Polar Research, Tokyo, Japan; 4973.

Harley, S.L. 1998b. Ultrahigh temperature granulite metamorphism $\left(1050^{\circ} \mathrm{C}, 12 \mathrm{kbar}\right)$ and decompression in garnet $(\mathrm{Mg} 70)$ - orthopyroxene-sillimanite gneisses from the Rauer Group, East Antarctica. Journal of Metamorphic Geology 16, 541-562.

Harley, S.L. 2004. Extending our understanding of ultrahigh temperature crustal metamorphism. Journal of Mineralogical and Petrological Sciences 99, 140-158.

Harley, S.L., Green, D.H. 1982. Garnet-orthopyroxene barometry for granulites and peridotites. Nature 300, 697-701.

Harley, S.L., Motoyoshi, Y. 2000. Al zoning in orthopyroxene in a sapphirine quartzite: evidence for $>1120^{\circ} \mathrm{C}$ UHT metamorphism in the Napier Complex, Antarctica, and implications for the entropy of sapphirine. Contributions to Mineralogy and Petrology 138, 293-307.

Hensen, B.J., Green, D.H. 1973. Experimental study of the stability of cordierite and garnet in pelitic compositions at high pressures and temperatures - III. Synthesis of experimental data and geological applications. Contributions to Mineralogy and Petrology 38, 151-166.

Hensen, B.J., Harley, S.L. 1990. Graphical analysis of P-T-X relations in granulite facies metapelites. In: High Temperature Metamorphism and Crustal Anatexis, Ashworth, J.R., Brown, M. (eds). Unwin Hyman, London; 427-457.

Holdaway, M.J., Lee, S.M. 1977. Fe-Mg cordierite stability in high grade pelitic rocks based on experimental, theoretical, and natural observations. Contributions to Mineralogy and Petrology 63, 175-198.

Holland, T.J.B., Powell, R. 1996. Thermodynamics of order-disorder in minerals. II. Symmetric formalism applied to solid solutions. American Mineralogist 81, 1425-1437.

Holland, T.J.B., Powell, R. 1998. An internally consistent thermodynamic data set for phases of petrological interest. Journal of Metamorphic Geology 16, 309-343.

Holland, T.I.M., Powell, R. 2001. Calculation of phase relations involving haplogranitic melts using an internally consistent thermodynamic dataset. Journal of Petrology 42, 673-683.

Hollis, J.A., Harley, S.L. 2003. Alumina solubility in orthopyroxene coexisting with sapphirine and quartz. Contributions to Mineralogy and Petrology 144, 473-483.

Johnson, T., Brown, M. 2004. Quantitative constraints on metamorphism in the Variscides of southern Brittany - A complementary pseudosection approach. Journal of Petrology 45, 1237-1259.

Johnson, T.E., Brown, M., Solar, G.S. 2003a. Low-pressure subsolidus and suprasolidus phase equilibria in the MnNCKFMASH system: constraints on conditions of regional metamorphism in western Maine, northern Appalachians. American Mineralogist 88, 624-638.

Johnson, T.E., Gibson, R.L., Brown, M., Buick, I.S., Cartwright, I. 2003b. Partial melting of metapelitic rocks beneath the Bushveld Complex, South Africa. Journal of Petrology 44, 789-813.

Kamineni, D.C., Rao, A.T. 1988. Sapphirine granulites from the Kakanuru area, Eastern Ghats, India. American Mineralogist 73, 692-700. 
Kawasaki, T., Matsui, Y. 1983. Thermodynamic analysis of equilibria Involving olivine, orthopyroxene and garnet. Geochimica et Cosmochimica Acta 47, 1661-1680.

Kelsey, D.E. 2008. On ultrahigh-temperature crustal metamorphism. Gondwana Research 13, 1-29.

Kelsey, D.E., Powell, R., Wilson, C.J.L., Steele, D.A. 2003a. (Th + U)-Pb monazite ages from Al-Mg-rich metapelites, Rauer Group, east Antarctica. Contributions to Mineralogy and Petrology 146, 326-340.

Kelsey, D.E., White, R.W., Powell, R. 2003b. Orthopyroxene-sillimanitequartz assemblages: distribution, petrology, quantitative P-T-X constraints and P-T paths. Journal of Metamorphic Geology 21, 439453.

Kelsey, D.E., White, R.W., Powell, R. 2005. Calculated phase equilibria in $\mathrm{K}_{2} \mathrm{O}-\mathrm{FeO}-\mathrm{MgO}-\mathrm{Al}_{2} \mathrm{O}_{3}-\mathrm{SiO}_{2}-\mathrm{H} 2 \mathrm{O}$ for silica-undersaturated sapphirinebearing mineral assemblages. Journal of Metamorphic Geology 23, 217 239.

Kerrick, D.M., Jacobs, G.K. 1981. A modified Redlich-Kwong equation for $\mathrm{H}_{2} \mathrm{O}, \mathrm{CO}_{2}$, and $\mathrm{H}_{2} \mathrm{O}-\mathrm{CO}_{2}$ mixtures at elevated pressures and temperatures. American Journal of Science 281, 735-767.

Lal, R.K. 1993. Internally consistent recalibrations of mineral equilibria for geothermobarometry involving garnet-plagioclase-quartz assemblages and their applications to the south Indian granulites. Journal of Metamorphic Geology 11, 855-866.

Lal, R.K. 2003. Metamorphic evolution of granulites from southern Indian Shield. In: Milestones in petrology and future perspectives, Mohan, A. (ed.), Memoir 52, - Geological Society of India, Banglore, 61-108.

Lal, R.K., Ackermand, D., Upadhyay, H. 1987. P-T-X relationships deduced from corona textures in sapphirine-spinel-quartz assemblages from Paderu, Southern India. Journal of Petrology 28, 1139-1168.

Lavrent'eva, L.V., Perchuk, L.L. 1990. Orthopyroxene-garnet geothermometer: experiments and theoretical treatment of data base. Doklady Akademi NaukSSR 260, 73-734.

Lee, H.Y., Ganguly, J. 1988. Equilibrium compositions of coexisting garnet and orthopyroxene-experimental determinations in the system FeO-MgO- $\mathrm{Al}_{2} \mathrm{O}_{3}-\mathrm{SiO}_{2}$, and applications. Journal of Petrology 29, $93-$ 113.

Lopez-Carmona, A., Abati, J., Reche, J. 2010. Petrologic modeling of chloritoid-glaucophane schist from the NW Iberian Massif. Gondwana Research 17, 377-391.

Masago, H., Omori, S., Maruyama, S. 2009. Counter-clockwise prograde P-T path in collisional orogeny and water subduction at the PrecambrianCambrian boundary: the ultrahigh-pressure pelitic schist in the Kokchetav massif, northern Kazakhstan. Gondwana Research 15, 137-150.

Mohan, A., Tripathi, P., Motoyoshi, Y. 1997. Reaction history of sapphirine granulites and a decompressional P-T path in a granulite complex from the Eastern Ghats. Proceedings of the Indian Academy of Sciences, Earth and Planetary Sciences 106, 115-129.

Moraes, R., Brown, M., Fuck, R.A., Camargo, M.A., Lima, T.M. 2002. Characterization and P-T evolution of melt-bearing ultrahigh-temperature granulites: an Example from the Anápolis-Itauçu Complex of the Brasília Fold Belt, Brazil. Journal of Petrology 43, 1673-1705.

Mukhopadhyay, D., Basak, K. 2009. The Eastern Ghats Belt-a polycyclic granulite terrain. Journal of the Geological Society of India 73, 489-518.

Mukhopadhyay, A.K., Bhattacharya, A. 1997. Tectonothermal evolution of the gneiss complex at Salur in the Eastern Ghats Granulite Belt of India. Journal of Metamorphic Geology 15, 719-734.

Nasipuri, P., Bhattacharya, A., Das, S. 2009. Metamorphic reactions in dry and aluminous granulites: a Perple_X $P-T$ pseudosection analysis of the influence of effective reaction volume. Contributions to Mineralogy and Petrology 157, 301-311.

Nickel, K.G., Green, D.H. 1985. Empirical geothermobarometry for garnet peridotites and implications for the nature of the lithosphere, kimberlites and diamonds. Earth and Planetary Science Letters 73, 158-170.

Nishimiya, Y., Tsunogae, T., Santosh, M. 2010. Sapphirine + quartz corona around magnesian $\left(\mathrm{X}_{\mathrm{Mg}} \sim 0.58\right)$ staurolite from the PalghatCauvery Suture Zone, southern India: evidence for high-pressure and ultrahigh-temperature metamorphism within the Gondwana suture. Lithos 114, 490-502.
Owen, J.V., Greenough, J.D. 1991. An empirical sapphirine-spinel MgFe exchange thermometer and its application to high grade xenoliths in the Popes Harbour dyke, Nova Scotia, Canada. Lithos 26, 317-332.

Pal, S., Bose, S. 1997. Mineral reactions and geothermobarometry in a suite of granulite facies rocks from Paderu, Eastern Ghats granulite belt: a reappraisal of the P-T trajectory. Proceedings of the Indian Academy of Sciences, Earth and Planetary Sciences 106, 77-89.

Perchuk, L.L., Aranovich, L.Y., Podlesskii, K. 1985. Precambrian granulites of the Aldan shield, eastern Siberia, USSR. Journal of Metamorphic Geology 3, 265-310.

Perkins, D., Chipera, S.J. 1985. Garnet-orthopyroxene-plagioclase-quartz barometry: refinement and application to the English River subprovince and the Minnesota River valley. Contributions to Mineralogy and Petrology 89, 69-80.

Perkins, D., Newton, R.C. 1981. Charnockite geobarometers based on coexisting garnet-pyroxene-plagioclase-quartz. Nature 292, 144146.

Powell, R., Holland, T.J.B. 1999. Relating formulations of the thermodynamics of mineral solid solutions; activity modeling of pyroxenes, amphiboles and micas. American Mineralogist 84, 1-14.

Powell, R., Holland, T., Worley, B. 1998. Calculating phase diagrams involving solid solutions via non-linear equations, with examples using THERMOCALC. Journal of Metamorphic Geology 16, 577-588.

Reche, J., Martinez, F.J. 1996. GPT: an Excel spreadsheet for thermobarometric calculations in metapelitic rocks. Computers and Geosciences 22, 775-784.

Rickers, K., Mezger, K., Raith, M.M. 2001a. Evolution of the continental crust in the Proterozoic Eastern Ghats Belt, India and new constraints for Rodinia reconstruction: implications from $\mathrm{Sm}-\mathrm{Nd}, \mathrm{Rb}-\mathrm{Sr}$ and $\mathrm{Pb}-\mathrm{Pb}$ isotopes. Precambrian Research 112, 183-210.

Rickers, K., Raith, M., Dasgupta, S. 2001b. Multistage reaction textures in xenolithic high- $\mathrm{MgAl}$ granulites at Anakapalle, Eastern Ghats Belt, India: examples of contact polymetamorphism and infiltration-driven metasomatism. Journal of Metamorphic Geology 19, 561-580.

Saha, L., Bhowmik, S.K., Fukuoka, M., Dasgupta, S. 2008. Contrasting episodes of regional granulite-facies metamorphism in enclaves and host gneisses from the Aravalli-Delhi Mobile Belt, NW India. Journal of Petrology 49, 107-128.

Santosh, M., Kusky, T. 2010. Origin of paired high pressure-ultrahightemperature orogens: a ridge subduction and slab window model. Terra Nova 22, 35-42.

Santosh, M., Maruyama, S., Sato, K. 2009b. Anatomy of a Cambrian suture in Gondwana: Pacific-type orogeny in southern India? Gondwana Research 16, 321-341.

Santosh, M., Sajeev, K., Li, J.H., Liu, S.J., Itaya, T. 2009a. Counterclockwise exhumation of a hot orogen: the paleoproterozoic ultrahightemperature granulites in the North China Craton. Lithos 110, 140152.

Santosh, M., Tsunogae, T., Li, J.H., Liu, S.J. 2007. Discovery of sapphirine-bearing $\mathrm{Mg}$-Al granulites in the North China Craton: implications for Paleoproterozoic ultrahigh-temperature metamorphism. Gondwana Research 11, 263-285.

Sanyal, S., Fukuoka, M. 1995. P-T-D history of granulites from Anakapalle, Eastern Ghats - evidence for polyphase (?) granulite metamorphism. Memoirs-Geological Society of India 34, 125-141.

Sarkar, M., Gupta, S., Panigrahi, M.K. 2007. Disentangling tectonic cycles along a multiply deformed terrane margin: structural and metamorphic evidence for mid-crustal reworking of the Angul granulite complex, Eastern Ghats Belt, India. Journal of Structural Geology 29, 802-818.

Sarkar, S., Santosh, M., Dasgupta, S., Fukuoka, M. 2003. Very high density $\mathrm{CO}_{2}$ associated with ultrahigh-temperature metamorphism in the Eastern Ghats granulite belt, India. Geology 34, 51-54

Sen, S.K., Bhattacharya, A. 1984. An orthopyroxene-garnet geothermometer and its application to Madras Charnockites. Contributions to Mineralogy and Petrology 88, 64-71.

Sen, S.K., Bhattacharya, S., Acharyya, A. 1995. A multi-stage pressuretemperature record in the Chilka Lake granulites: the epitome of the metamorphic evolution of Eastern Ghats, India? Journal of Metamorphic Geology 13, 287-298. 
Sengupta, P., Dasgupta, S., Bhattacharya, P.K., Fukuoka, M., Chakraborti, S., Bhowmick, S. 1990. Petro-tectonic imprints in the sapphirine granulites from Anantagiri, Eastern Ghats mobile belt, India. Journal of Petrology 31, 971-996.

Sengupta, P., Dasgupta, S., Ehl, J., Raith, M. 1997. Thermobaric evolution of a suite of $\mathrm{Mg}-\mathrm{Al}$ granulites from Paderu: further evidence for a ACW P-T path in the Eastern Ghats Belt, India:. European Journal of Mineralogy 9, 331 .

Sengupta, P., Karmakar, S., Dasgupta, S., Fukuoka, M. 1991. Petrology of spinel granulites from Araku, Eastern Ghats, India, and a petrogenetic grid for sapphirine-free rocks in the system FMAS. Journal of Metamorphic Geology 9, 451-459.

Sengupta, P., Sen, J., Dasgupta, S., Raith, M., Bhui, U.K., Ehl, J. 1999. Ultra-high temperature metamorphism of metapelitic granulites from Kondapalle, Eastern Ghats Belt: implications for the Indo-Antarctic correlation. Journal of Petrology 40, 1065-1087.

Shaw, R.K., Arima, M. 1996. Mineral chemistry, reaction textures, thermobarometry and P-T path from orthopyroxene granulites of Rayagada, Eastern Ghats, India. Journal of Southeast Asian Earth Sciences 14, 175184.

Simmat, R., Raith, M.M. 2008. U-Th-Pb monazite geochronometry of the Eastern Ghats Belt, India: timing and spatial disposition of poly-metamorphism. Precambrian Research 162, 16-39.
Thompson, A.B. 1976. Mineral reactions in pelitic rocks: II. Calculation of some P-T-X (Fe-Mg) phase relations. American Journal of Science 276, 425-454.

Thompson, J.B., Hovis, G.L. 1979. Entropy of Mixing in Sanidine. American Mineralogist 64, 57-65.

Tindle, A.G., Webb, P.C. 1994. Probe-Amph-a spreadsheet program to classify microprobe-derived amphibole analyses. Computer Geosciences 20, 1201-1228.

Tsunogae, T., Santosh, M. 2006. Spinel-sapphirine-quartz bearing composite inclusion within garnet from an ultrahigh-temperature pelitic granulite: implications for metamorphic history and $P-T$ path. Lithos 92, 524-536.

Wells, P.D.R. 1977. Pyroxene thermometry in simple and complex systems. Contributions to Mineralogy and Petrology 62, 129-139.

White, R.W., Powell, R. 2002. Melt loss and the preservation of granulite facies mineral assemblages. Journal of Metamorphic Geology 20, 621-632.

White, R.W., Powell, R., Holland, T.J.B. 2001. Calculation of partial melting equilibria in the system: $\mathrm{Na}_{2} \mathrm{O}-\mathrm{CaO}-\mathrm{K}_{2} \mathrm{O}-\mathrm{FeO}-\mathrm{MgO}-\mathrm{Al}_{2} \mathrm{O}_{3}-$ $\mathrm{SiO}_{2}-\mathrm{H}_{2} \mathrm{O}$ (NCKFMASH). Journal of Metamorphic Geology 19, 139153.

Zeh, A., Holness, M.B. 2003. The effect of reaction overstep on garnet microtextures in metapelitic rocks of the Ilesha Schist Belt, SW Nigeria. Journal of Petrology 44, 967-991. 